\title{
Yanan Ormanlarda 50 Gün: Yaşar Kemal'in Gözleminden Ormancılık Dersleri
}

\author{
Cihan ERDÖNMEZ ${ }^{1 *}$ \\ ${ }^{1}$ İstanbul Üniversitesi-Cerrahpaşa, Orman Fakültesi, Ormancılık Politikası ve Yönetimi Anabilim Dalı, 34473, \\ Bahçeköy-Sarıyer/ISTANBUL
}

\section{Öz}

Dünya edebiyatında doğaya olan ilgi 1990'lardan itibaren çevreci eleştiri (ekokritizm) denilen bir akım oluşturmuştur. Yaşar Kemal yaşadığı toplumla birlikte doğayı bir bilim adamı titizliğiyle gözlemleyip eserlerinde yansıtan bir yazar olarak Türk edebiyat tarihine damga vurmuştur. Yaşar Kemal 1951-1963 yılları arasında Cumhuriyet Gazetesi'nde fikra yazarı olarak çalışmış ve röportajlar yapmıştır. Yanan Ormanlarda 50 Gün orman yangınlarına ilişkin bir röportaj dizisi olarak önce gazetede yayımlanmış, sonra da Türkiye Ormancılar Cemiyeti tarafından kitap haline dönüştürülmüştür. Bu çalışma Yanan Ormanlarda 50 Gün adlı eserden yola çıkarak dönemin ormanlar ve ormancılığına ilişkin çıkarımlarda bulunmayı amaçlamıştır. Eserde Akdeniz ve Ege bölgelerindeki ormanların insan eliyle büyük ölçüde tahrip ediliği görülmektedir. Devlet ormancılık işletmeciliği 1937 yılından itibaren başlamış, ancak müteahhit işletmeciliğinin son örnekleri 1945 yılına kadar devam etmiştir. Devlet orman işletmeleri bir yandan üretim yaparken bir yandan da ormanları korumaya çalışmıştır. Ancak bir yandan 1937 öncesi dönemdeki müteahhit işletmeciliğinin izleri diğer yandan kırsal yoksulluk orman tahriplerini devam ettirmiştir. O dönemde ormanı yakarak, ağaçların kabuğunu soyarak, keserek tarla açmak, tapulu kesimler, kaçakçılık ve keçi otlatması ön plana çıkmaktadır.

Anahtar Kelimeler: Yaşar Kemal, Orman, Ormancılık, Ekokritizm, Orman yangınları.

\section{Days in the Burning Forests: Forestry Lessons in the Observation of Yaşar Kemal}

\begin{abstract}
The interest in nature in the world literature has created a trend called ecocritism since the 1990s. Yaşar Kemal, as a writer, marked the history of Turkish literature and observed the society and the nature he lived in the way that meticulousness of a scientist and reflected it in his works. Yaşar Kemal worked as a columnist and interviewer in Cumhuriyet Newspaper between 1951 and 1963. 50 Days in the Burning Forests has been first published as an interview series in the newspaper and then has been published as a book by Foresters' Association of Turkey. This study proposes to make inferences about forests and forestry of the period based on the 50 Days in the Burning Forests. The work shows that the forests in the Mediterranean and Aegean regions were largely destroyed by antropogenic impact. The state forest management started from 1937 but the last examples of contractor management continued until 1945. State forest enterprises tried to protect forests while producing. However, the traces of the contractor management of the pre-1937 period and rural poverty continue forest destruction. In that period, burning, peeling and cutting the trees to get agricultural land, cutting of the trees on private lands, illegal tree cutting and goat grazing in the forests were the most important forest degradation types.
\end{abstract}

Keywords: Yaşar Kemal, Forest, Forestry, Ecocriticism, Forest fires. 


\section{Giriş}

Edebiyat Arapça “edeb” kelimesinden gelmektedir ve bu kelime zamanla güzel ahlak, insanı kötülüklerden koruyan, iyiliğe sevk eden meleke, güzel huy anlamı kazanmıştır (Aktaş, 2009). Edebiyatın, etimolojik kökeni ile uyumlu olarak iyiyi ve doğruyu; gerçeği aramak gibi bir işlevi bulunmaktadır. Gerçek çoğunlukla akıl ve duyular yoluyla ve bilimsel gözlemlerle aranır. Ancak sanatçının da sezgisel gerçeği aramak gibi bir işlevi bulunmaktadır (Moran, 2002).

Edebiyatın ve edebiyatçıların genelde doğa ve çevreye özelde ise ormanlara ilişkin gerçeklerle ilgisini çok eski zamanlara dayandırmak olanaklı değildir. Önce Avrupa'da görülen sonra da Türkiye'de etkisi hissedilen romantizm akımı bu açıdan başlangıç noktası olarak düşünülebilir. Romantizm, bir ekol olmaktan çok belirli varlıkları, konu ve durumları algılama biçimidir; Romantik sanatçı, insanın kendisini tanıyıp anlamlandırmasının yanı sıra Tanrı, doğa ve diğer varlıklarla olan ilişkilerini de düzenlemeye çalışır (Özbek, 2017). Amerikan yazınında doğanın haklarını savunma geleneği 19. yüzyılın ikinci yarısından itibaren başlamış ve 1870'li yıllarda ünlü doğa yazarı ve natüralist John Muir ilk kez doğanın yaşam hakkını savunup, yazılarında insanın çevreye karşı sorumluluk taşıdığını dile getirmeye başlamıştır (Özdağ, 2017).

Diğer yandan, edebiyatta doğaya yönelik ilgi zamanla çevreci eleştiri (ekokritizm) adı verilen bir akımın oluşmasına yol açmıştır. Çevreci eleştiri günümüzün çevresel krizi ile bağlantılara ulaşmak için edebiyata çağrıda bulunmaktadır (Opperman, 1999). Çevreci eleştirinin vurguladığı ana düşünce ve amaç, doğanın dengesinin bozulmamasını sağlayarak insanın daha kaliteli yaşam sürmesini olanaklı kılmaktır (Sümer, 2016).

Çevreci eleştiri 1990'ların başında organize bir girişim olarak, artan bir hızla yayılmıştır (Buell et al, 2011). Glen Love 1992 yılında Edebiyat ve Çevre Çalışmaları Derneğini kurmuş ve bu dernek yalnızca on yıl içinde bin üyeye ulaşarak Japonya, Avustralya, İngiltere ve Kore'de şubeler açmıştır (Westling, 2006). Çevreci eleştiri derin ekoloji, ekofeminizm, toplumsal ekoloji, ekopsikoloji gibi yaklaşımlardan beslenmiştir (Ayaz, 2014). Çevreci eleştiri iki ana dalga ya da etapta, dünya çapında bir büyüyen harekete evrilmiştir (Buell et al, 2011).

a) Korumacı çevrecilik; çevre etiği, yerel ve biyo-bölgesel bağlantılara önem verme, kendi doğasının önceliği ve bunları yansitan edebi hayal formları.

b) Kolektif deneyime önem veren daha sosyosentrik bir çevre etiği ve küresel bir çevresel aidiyet düzeyi.

Türk edebiyatında doğanın belki de en yoğun olarak ele alınışı geleneksel halk edebiyatında söz konusu olmuştur. Halk edebiyatı aşk, ölüm, yiğitlik gibi konularla birlikte doğayı da odağına almıştır. Halk edebiyatında yer almayan roman Türk edebiyatında geç gelişen türlerden biridir. Türk romanında Tanzimat dönemi sanatçılarından Namık Kemal'in romantizmi benimseyerek eserlerinde doğaya yer vermeye başladığı görülmektedir. Örneğin yazar İntibah’ta uzun Çamlıca tasvirleri yapmaktadır (Özbek, 2017).

Bununla birlikte, 1950-1970 dönemine Türk edebiyatına damgasını vuran bir köy akımı yaşanmış, bunda Köy Enstitülü yazarlar kadar diğer yazarların da katkısı olmuştur (Çankaya, 2013). Bu akımın ortaya çıkardığı eserler aynı zamanda çok okunmuş ve edebiyat tartışmalarının odağında tutulmuş olmasına karşın bu konu hakkında akademik araştırma çok az yapılmıştır (Irmak, 2018). Daha sonra köy olgusu Türk edebiyatının odağından düşmüştür. Bununla birlikte köy temalı edebi eserler bilimsel araştırmaların bıraktığı boşlukları doldurmak açısından son derece önemli bir rol üstlenmiştirler.

Cumhuriyet dönemi Türk romanında ise modern kentin yarattığı sıkıntılarla birlikte kentten doğaya kaçma ve sığınma arzusu kendini gösteren temalardan biridir (And1, 2006). Ancak, Yaşar Kemal bu genellemenin dışında değerlendirilmesi gereken bir yazardır. Onun eserlerinde doğa, özellikle Çukurova ve Toroslar daima ana aktörlerden biri olmuştur.

Yaşar Kemal'in eşsiz üslubundan, modern zamanların Homeros'u olarak epiği yeniden canlandırmasından söz edilse bile, bu nitelikler tek başına Yaşar Kemal'in edebiyat tarihinde kendisine verilen yeri açıklamakta yetersiz kalmaya mahkumdur (Armağan, 2015). Yaşar Kemal'in yaşadığı toplumsal koşullar, toplumsal eşitsizliklerden bürokrasideki sorunlara, önemini yitiren kültürel değerlerden çevrenin bozulan dengesine kadar, gözlemlediği her şey romanlarında yerini almıştır (Şeker, 2019a). Yaşar Kemal modern Türk romanında dünyayı, doğduğu coğrafyayı, insanı, toplumu, doğayı derinden anlayan, çözümleyen ve aktaran bir yazardır (Şeker, 2019b). Yaşar Kemal romanlarında Anadolu insanını canlı yaşam renkleriyle işlemiş, insanları somut ve derinlikli, doğayı da zengin, canlı, kıpır kıpır vermiştir (Aydemir ve Yıımaz, 2018). Yaşar Kemal kişiyle doğayı bütünleştirerek ele almış, çevre-kişi bütünleşmesini gerçekleştirmiştir (Önertoy, 1983). Yazar Demirciler Çarşısı Cinayeti'nde romanın coğrafyasını bir botanikçi gibi işlerken Deniz Küstü’de çevresel sorunları distopyavari bir tarzla dile 
getirmektedir (Şeker, 2019a). Hüyükteki Nar Ă̆acı adlı romanında yer alan şu satırlar yazıldığı tarih (1977) dikkate alınırsa, belki de Türk edebiyatındaki çevreci eleştirinin ilk örneği sayılabilir:

"Çok kutsal ă̆aç vardı Çukurovada. ${ }^{1}$ Buradan denize kadar nar ăgacı ormanıydı Çukurova. Yaz bahar aylarında bir al çiçek açardı narlar, toprak buradan Ayasa kadar apal kesilir, deniz gibi dalgalanırdı. Kara yılanlar sevişirdi nar çiçeklerinin altında, ocaktaki demir gibi kıpkızl olarak. Hiç ăgaç kalmadı ovada, bütün ăgaçları kökten söktüler. Şimdi ne nar, ne meşe, ne karaçalı, ne çam, hiçbir ă̆aç kalmadı Çukurovada, yok. Şu ovada kutsal hiçbir şey kalmadı ki nar ă̆acı kalsin..."

Yaşar Kemal ilk yapıtlarından itibaren doğayla ilgilenmiş, insanın doğayla olan ilişkisini betimlemek için özel bir dil kurma arayışında olmuştur (Ayaydın, 2003). Ancak doğaya olan ilgisini yalnızca edebi eserlerde ortaya koymamıştır. Yazar 1951-1963 yılları arasında Cumhuriyet Gazetesi'nde fikra ve röportaj yazarı olarak çalışmıştır. Söz konusu dönem Türkiye'nin sosyal, ekonomik ve siyasi açıdan büyük değişimler yaşamasına sahne olmuştur. 1946 yılında çok partili hayata geçilmiş, 1950 yılında Demokrat Parti iktidara gelmiştir. Dış yardımlar, tarımda makineleşme ve tarım yapılan alanların genişlemesi (Oktar ve Varlı, 2010) temelinde yaşanan değişimler ülke ormanları üzerinde büyük bir baskının oluşmasına yol açmıştır. Bu dönemde ormanların korunması öyle karmaşık bir hal almıştır ki, ormanların nasıl korunacağı konusunda endişeli bir bekleyiş yaşanmıştır (Gümüş, 2018). Ormanlar bir yandan kaçak ağaç kesimi, açma ve yerleşme gibi suçlarla zarar görürken diğer yandan büyük orman yangınlarıyla tahrip olmuştur. Bu sırada Cumhuriyet Gazetesi, Yaşar Kemal'i orman yangınlarının nedenlerini araştırmak üzere röportajlar yapmak üzere görevlendirmiştir. Gazetede yayımlanan röportajlar daha sonra Türkiye Ormancılar Cemiyeti (bugünkü adı Türkiye Ormancılar Derneği) tarafından 1955 yılında kitap haline getirilmiştir. Cemiyet, kitaba yazdığı önsözde şöyle demektedir (Kemal, 1955):

“Cumhuriyet Gazetesi'nin orman yangınları üzerine röportaj teşebbüsünde büyük muvaffakiyeti röportajı yapacak kimseyi isabetle seçmiş olmasında görünüyor. Çünki Yaşar Kemal sadece bir gazete yazarı değildir. Aynı zamanda kavrayıcı ve sürükleyici bir üslûp sahibidir. Asıl mühimi yazarın orman dertlerini kendine dert edinmiş olmasıdır. "

Yaşar Kemal "Yanan Ormanlarda 50 Gün” adıyla yayımlanan röportajları hakkında, kendisiyle 2012 yılında yapılan bir görüşmede şöyle demektedir (Kayayerli, 2012):

“En iyi röportajım, “Yanan Ormanlarda Elli Gün”dür. O röportajı yapmak için İstanbul Üniversitesi Orman Fakültesine gittim. O fakültede 5-6 ay kadar çalıştım; okumalar yaptım. Orman için ne diyorlar, diye araştırdım. Ne kadar yazı varsa, kitap varsa okudum. Hatta Almanya'dan büyük bir ormancı gelmişti, dil bilmediğim halde, dil bilen bir arkadaşıma konuşmayı tercüme ettirdim. Şu an hâlâ müthiş bir orman kültürüm var. Röportaj için yaptım bunları ben...”

Görüldüğü üzere Yaşar Kemal yalnızca çok iyi bir gözlemci değil, aynı zamanda titiz bir araştırmacıdır. Uzun ve derin bir hazırlık aşamasından sonra gerçekleştirilen ve yayımlanan röportajlar Türkiye Ormancılığı açısından çok önemli bilgiler içermektedir. Bu makalenin amacı, bilimsel amaçlarla hazırlanmayan ancak bir bilim adamı titizliğiyle gerçekleştirilip kaleme alınan röportajların içerdiği, özellikle ormancılık tarihi açısından değer taşıyan ve günümüz ormancılığına da 1şık tutan bilgileri gün yüzüne çıkarmaktır.

\section{Materyal ve Metot}

\subsection{Materyal}

Çalışmanın ana materyali Yaşar Kemal tarafından yazılarak Cumhuriyet Gazetesi’nde yayımlanan ve daha sonra Türkiye Ormancılar Cemiyeti tarafından kitap haline getirilen "Yanan Ormanlarda 50 Gün” adlı röportajlardır (Kemal, 1955). Bu röportajlar sonraki yıllarda Yapı Kredi Yayınları tarafından da kitap olarak yayımlanmıştır (Kemal, 2017). Ancak bu çalışmada Türkiye Ormancılar Cemiyeti tarafından yayımlanan kitap kullanılmıştır.

\subsection{Metot}

Öncelikle edebiyat ve doğa, çevreci eleştiri ve Yaşar Kemal konularında literatür taraması yapılmış ve elde edilen

\footnotetext{
${ }^{1}$ Yaşar Kemal eserlerinde kesme işaret kullanmamıştır. Yazarın üslubun bir parçası olan bu özelliğine saygı gösterilerek ondan yapılan alıntılar aynı şekilde aktarılmıştır.
} 
eserler incelenmiştir. Literatür taramasının bir diğer ayağını da röportajların yapıldı̆̆ı dönem (1950’ler) koşullarını ve ormancılığını anlatan yayınlar oluşturmuştur.

Daha sonar Yanan Ormanlarda 50 Gün adlı eser içerik analizi yöntemiyle incelenmiştir. Bu amaçla röportajlarda yer alan ve ormanlara zarar veren temel ormancılık sorunlarının dile getirildiği bölümler işaretlenmiştir. Bunlar kendi içinde ana gruplara ayrılarak sınıflandırılmıştır. Bu gruplar sekiz ana başlık altında toplanmıştır. Bunlar;
a) Ormanlar ve ormansızlaşma,
b) Ormancilar,
c) Orman köyleri,
d) Orman yangınları,
e) Açmacilık,
f) Orman işletmeciliği,
g) Tapulu kesimler,
h) Diğerleri.

Eserde geçen ve yukarıda sıralanan ana gruplarla ilgili olan kısımlar incelenmiş ve çıkarımlarda bulunulmuştur. $\mathrm{Bu}$ çıkarımlarda bulunulurken konularla ilgili bilimsel yayınlar da göz önünde bulundurulmuş ve yapılan çıkarımların daha önce mevcut bilgilerle uyumu test edilmiştir.

\section{Bulgular ve Tartışma}

\subsection{Ormanlar ve ormansızlaşma}

Yaşar Kemal bu röportajları yapmak için İçel'den Bandırma'ya bütün ormanları gezdiğini belirtir. ${ }^{2}$ Bu coğrafyada yazarın karşısına çıkan ormanlarda genellikle hakim olan ağaçlar çam, göknar ve sedirdir. Bu durum röportajlarda şöyle aktarılır: ${ }^{3}$

"Çam kabuğu kokuludur. Ağaçlar içinde en çok çamın kabuğu kokar böyle. Yel esince iki saatlik öteden çam kokusunu getirebilir. Bir de Kamalak vardır. Ormancılar sedir koymuşlar adını. Ondaki koku da çama yakın bir kokudur. Köknarı da unutmamalı. Bunlar ormanlarda üç sacayağıdır."

Yazarın gördüğü orman manzaraları büyük çoğunlukla yakılmış, tahrip edilmiş, tarlaya dönüştürülmüş doğa parçalarıdır. Aslında bu gözlem yüzyıllardır devam eden aşırı kullanımların ve ormanları diğer arazi kullanım türlerine dönüştürmenin bir sonucudur. Bundan sonraki bölümlerde de görüleceği üzere yakılarak, tarla açılarak, hayvan ve özellikle keçi otlatılarak, ormanların devamlılı̆̆ını gözetmeyen işletmecilik uygulamaları gerçekleştirerek ve yasal düzenlemelerle ormanların tahrip olmasına yol açarak sürüp giden akışın ortaya çıkardığı sonuç röportajlarda açıkça kendini göstermektedir.

Ormanlar öylesine tahrip edilmiştir ki, köylere, ovalara yakın yerlerde, kolay ulaşılabilir alanlarda neredeyse hiç orman kalmamıştır. Yazarın tahtacıların çalışma alanlarını anlatırken kullandığı cümleler bu durumun açık kanıtı niteliğindedir: ${ }^{4}$

“Çalıştıkları yerler hep sarplarda. Uzak dağların doruklarında...”

Ali Çavuş adlı tahtacının hem yazarın sözlerini onaylayan hem de ormanların sarp dağlık alanlar dışında kalmadığını açıkça ortaya koyan şu sözleri de röportajlarda kendine yer bulmaktadır: ${ }^{5}$

"Bir de düz yerde hiç kesim yapmıyoruz yıllardan beri... Hep sarp yerlerden kesim yapıyoruz. Bu ise bizim için ölümden beter. Çünkü ormancılara göre, eteklerde orman kalmamış. Daha bir elli yıl eteklerden orman kesilmezmiş..."

Yazar, insanların en tatlılarından diye tarif ettiği İzmir Orman İşletme Müdürü Hakkı Özkan'la yaptı̆̆g geziler ve

\footnotetext{
${ }^{2}$ Bölüm 3- Orman Kemirenler ve Kemirilen Ormanlar, s.23.

${ }^{3}$ Bölüm 3- Ormanı Kemirenler ve Kemirilen Ormanlar, s.22.

${ }^{4}$ Bölüm 14- Tahtacilar, s.77.

${ }^{5}$ Bölüm 14- Tahtacılar, s.79.
} 
sohbetler sonucunda oluşan düşüncelerini şu şekilde aktarmaktadır: ${ }^{6}$

"Bizimkiler orman ilmini de bize benzetmişlerdir. Makilik, baltalık, koruluk diye üç kısma ayırmışlar. Baltalıkla makilik dedikleri yerlere ver etmişler baltayı. Halbuki ormancılık ilminde yalnız bir orman vardır. Makilikler, baltalıklar dediklerimiz türlü sebeplerle dejenere olmuş ormanlardır. Bu ormanlar nasıl dejenere olmuşlardır? Gezdiğim gördüğüm yerlerde bütün ormancılar bunun üstünde durdular. Hakkı Özkan da ötekiler gibi...,

Orman İşletme Müdürü Hakkı Özkan ise aynı bölümde keçi otlatması nedeniyle tahrip olan ormanları pırnal meşesi üzerinden şu şekilde anlatmaktadır:

"Şu ă̆aca bakın. Bu ă̆aç yere yapışmışçasına yayılmıştır. Uzayamamasının sebebi keçidir. Çıkan dallarını yer, çıkan dallarını yer. Ăgaç da bu yüzden uzayamaz, yayılır. Bu ne ă̆acıdır? Pırnal meşesi. Bunun boyu iki karıştır. Halbuki beş metre boyunda pırnal meşesi vardır. Keçi bir ormanın üremesinin, gençlik yetiştirmesinin önüne geçer. Çıkan gençliği yer, çıkan gençliği yer.

“...Ben şimdiye kadar bu meşenin yarım metreyi geçmişini görmedim. Söyleseler de inanmazdım. Ama üç metreliğini, dört metreliğini gözümle gördüm. İnandım ki bu keçinin ettiğidir. Inandım ki bu dağlar keçinin kel bıraktı̆̆ dăglardır."

Orman yangınlarının sonuçları, yani ormanları tahrip eden etkisi yazar tarafindan özgün bir üslupla dile getirilmektedir: ${ }^{7}$

"Bir tepe çıktık. Bir tepe daha çıktık. Să̆ımız solumuz ormanlık... Genç ă̆açlar... Ama yangın görmemiş hiçbir gövde yok. Gövdeler kapkara. Bunlar geçen yılki, evvelki yılki yangından kalanlar... Bütün dăg az önce söndürülmüss bir ocak sanki... Yă̆mursu, ıslak ıslak bir yanık kokusu almış dünyayı. Adamın genzini yakıyor.

"Daha ötede aynı biçimde bir yangın yeri daha... Bir daha, bir daha... Ve artık ara ki bir yeşillik göresin...”

Yalnızca ormancılar, uzmanlar değil yöre halkı da ormanların zaman içerisinde ne kadar tahrip olduğunun farkındadır. Yazara rehberlik eden köylülerden biri olan İsmail Efendi bir noktada şöyle söyler: ${ }^{8}$

“Ben buraların çocuğuyum. Şu gördüğ̈̈n kel, topraksız, kayaları bıçak gibi çıkmış yamaçlar var ya, daha yeniyle kaplan girmez ormandı. Işste şimdi böyle...”

Yukarıdakilere benzer aktarımlar röportajlarda bolca yer almaktadır. Bunun dışında orman azalmasının özellikle toprak ve su koruma açısından önemi de röportaj yapılanlar tarafından sıklıkla dile getirilmektedir. Bu açıdan yine İzmir Orman İşletme Müdürü Hakkı Özkan'ın sözleri örnek olarak gösterilebilir: ${ }^{9}$

“Eski orman bölgeleri çırılçıplak... Dağlar öylesine soyunmuş, toprak öylesine akmış ki, dağların tepeleri, sırtları testere gibi akmış... Geçtiğimiz bir iki çay kıpkırmızı akıyordu. Yıl on iki ay hep böyle akarmış bu çaylar. Ormanlık bölgelerden gelen sular böyle değildir. Pırıl pırıldır. Dibine kitap düsse okunur. Öyle aydınlıktır. Çünkü taşıyacak toprak bulamaz.

“...Toprak taşınmasından böyle yüzlerce binlerce dere meydana gelmiş. Toprak akıyor babam akıyor. Bazı yerlerde de toprak kalmamış. Bu sefer taşlar akıyor. Çakıltaşları. İşte bu felaket...

“Ormanın altındaki çürümüş yapraklar suları sünger gibi emip sonra yavaş yavaş bırakırlar. Böylelikle sel olayı olmaz. Bazı Avrupa memleketleri baraj inşasına başlayacakları zaman, yıllar önce o suyun gözünün bulunduğu dağları ağaçlandırlyorlar, ondan sonradır ki baraj yapıyorlarmış..."

Ormanların yok olmasının ne tür yıkıcı sonuçlarının olacağını köylü de en az ormancılar kadar bilmektedir. Ne

\footnotetext{
${ }^{6}$ Bölüm 12- Sanki Çaresiz Dertler! s.92.

${ }^{7}$ Bölüm 2- İnsan ve Orman, s. 18.

${ }^{8}$ Bölüm 5- Ağaç Boğucuları ve Boğulan Ağaçlar, s.36.

${ }^{9}$ Bölüm 12- Sanki Çaresiz Dertler, s.93.
} 
var ki çaresizlik nedeniyle ormana zarar veren eylemelere devam etmek zorunda hissetmektedirler. Yazar sohbet ettiği Süleyman Ağa olarak aktarılan bir köylüye şöyle der: ${ }^{10}$

“Ama Süleyman Ă̆a, orman bir gün bitecek. Yağmurlar toprağl yıkayıp götürecek. Her yan sipsivri kayalardan, taşlardan ibaret kalacak. Yağmur yüzü görmeyeceksiniz yllın on iki ayında. O zaman ne keçi yetiştirebilecek, ne de ekin ekebileceksiniz."

Süleyman Ağa’nın yazara verdiği cevap köylünün çaresizliğinin en yalın açıklaması niteliğindedir:

"Bunu çok iyi biliyorum. Yakında, on yıla varmadan bir tek ağacın kalmayacağını, kurak olacağını, toprağın gideceğini hepinizden iyi biliyorum. Koy kendini benim yerime de keçi besleme, orman açma. Haydi koy. Koydun mu? Düşün bakalım."

Görüldüğü üzere İçel'den Bandırma'ya kadar ormanların durumu çok kötüdür. Alçak, düzlük yerlerde, köyler civarında hemen hiç orman kalmamış; ormanlar ya yakılarak, ya kesilerek ya da boğularak yok edilip tarlaya dönüştürülmüş veya keçi otlatması nedeniyle tahrip olmuştur. Orman denilebilecek boylu ağaçların bulunduğu alanlar ise ancak uzak dağların tepelerinde, kolay ulaşılamayacak bölgelerde kalmıştır.

\subsection{Ormancılar}

1937 yılında çıkarılan 3116 Sayılı Orman Kanunu'na kadar ormanların korunması ve işletilmesi ile ilgili olarak 1870 tarihli Orman Nizamnamesi hükümleri geçerlidir. Orman işletmeciliği müteahhitler tarafindan yapılmaktadır. 3116 sayılı yasa ile devlet orman işletmeciliği ilkesi benimsenmiş ve devlet orman işletmeleri kurulmaya başlanmıştır. Böylelikle ormancılar halkla ve köylüyle doğrudan ilişki kuran ve çoğu zaman onlarla karşı karşıya gelen bir duruma gelmişlerdir.

Yanan Ormanlarda 50 Gün'de ormancılara ilişkin bilgiler önemli bir yer tutmaktadır. Bu bilgiler hem yazarın gözlemleri hem de röportaj yapılanların ormancılar hakkındaki sözlerinden meydana gelmektedir. Yazar genellikle ormancılardan övgü ve takdirle söz etmekte, onlardan aldığı teknik bilgileri olduğu gibi aktarmaktadır. Ormancıların ormanı korumak için gösterdikleri insanüstü çabalar da esere yansımıştır. Bir yangına müdahale için ormancılarla birlikte giden yazarın şu satırlarına göz atmakta yarar bulunmaktadır: ${ }^{11}$

"Yollardan mı geçiyoruz, kayalardan, hendeklerden mi atllyoruz belli değil. İşletme müdürü makinayı delicesine sürüyor. Ne yol belli ne iz...”

"Ben de yangın yakın yerde belledimdi. Çık çık bitmiyor. Oluk oluk ter akıttyorum. En geride kaldım. İsletme müdürü geyik gibi firladı gitti. Tırmı ğı omzunda..."

Yazarın bahsettiği orman işletme müdürünün yangın karşısındaki çaresizliği ve bu çaresizliğini dışa vuran sözleri de ormancının orman ve memleket sevgisinin kanıtı niteliğinde: ${ }^{12}$

“... Ama benim bu rüzgârda hiç umudum yok. Söndüremeyeceğiz. Koca dağ yanacak. Hey be anasını. İște böyle. İşte böyle böyle memleket yanıyor. Bir memleket yanıyor, biz seyirci kallyoruz."

Yazarın İzmir bölgesindeki gezilerine eşlik eden İzmir Orman İşletme Müdürü Hakkı Özkan hakkındaki sözleri, hem onun ormancılara yaklaşımını hem de dönem ormancılarının genel özelliklerini özetler nitelikte: ${ }^{13}$

“... Hakkı Özkanda gördüğ̈̈m insanların en tatllarından... Her orman yangınında gözleri dolu doluveriyor. Toprak taşınması üstüne İzmir gazetelerinde epey de yayını var. İşinin adamı bir genç. "

Buna karşılık köylülerin ormancılar hakkındaki düşünceleri genel anlamda olumsuzdur. Bu olumsuzluk, ormandan koşullar nedeniyle yasalara aykırı olarak yararlanmak isteyen toplumsal kesimle ormanı yasalar doğrultusunda koruma sorumluluğuna sahip kamu görevlisi arasındaki olağan çatışma olarak yorumlanabilir. İbrahim Emmi'nin sözleri bu çatışmanın köylü tarafından görünüşünü özetlemektedir: ${ }^{14}$

\footnotetext{
${ }^{10}$ Bölüm 10- Keçiye ve Açmaya Karş1, s.57.

${ }^{11}$ Bölüm 1- Ormancılar ve Orman Yangınları, s. 8-9.

12 Bölüm 1- Ormancilar ve Orman Yangınları, s.9.

${ }^{13}$ Bölüm 12- Sanki Çaresiz Dertler, s. 91.

${ }^{14}$ Bölüm 2- İnsan ve Orman, s. 20.
} 
“... Ormanı biz korursak, o da bizi felâketten korur. Korur demek ne demektir? O sebepten köylü ormanı yakmaz. Ormanı koru ki dağın kel, suyun sel olmasın... Emme emmevelâkin şu ormancılarda da suç var azıcık. Eyiler, haslar emme, bir keser saplığı bile kestirmezler. Allahın yaktı̆̆ı ormanı köylüye bulurlar. Orman yurdun hem süsü hem gücüdür. Aaah şu ormancılarımız."

Görüldüğü üzere köylüler ormancının ormanı koruma çabalarını aşırı bulmakta ve kendiliğinden çıkan yangınlardan da köylüyü sorumlu tutmakla itham etmektedir. Köylü ormancıya böyle bakarken ormancının penceresinden görünen tablo ise bambaşka niteliktedir. Bu tabloyu Yaşar Kemal'e kılavuzluk yapan bakım memuru (Orman Muhafaza Memuru) İsmail Mardin şu şekilde aktarmaktadır: ${ }^{15}$

"Hoş geldin, safalar getirdin. Duydum ki orman hakkında yazı yazmak için dolaşlyormuşsunuz. Siz İstanbulda Cumhuriyet Gazetecisiymişsiniz. Hoş geldin, safalar getirdin. Şimdi siz sabır taşı olacak, bizim derdimizi dinleyeceksiniz. Bizde dert birçok, birçok ki, başımızdan aşkın. Ormancı demek dert kumkuması demektir. Ormancıya köylü düşman, keçi düşman, partiler düşman, ocaklar, bucaklar düşman, hele bizim gibi küçüklere herkes düşman... Amma vazifeni yaparsan düşman. Yapmazsan herkes... dost diyemem. Çokları gene düşman..."

Görevi ormanı korumak olan bir devlet memurunun herkesi kendine düşman olarak görmesi ve özellikle görevini yaptığında bu düşmanlığın arttığını vurgulaması, yukarıdaki sözlerin altı çizilmesi gereken kısmını oluşturmaktadır. Bu durumu yazar eserin bir başka bölümünde, Aydın Karacasu Orman İşletmesindeki izlenimlerini anlatırken ve işletme Müdürü Burhaneddin Şener’den söz ederken çok güzel özetlemektedir: ${ }^{16}$

“İ̧sletme Müdürü Burhaneddin Şener inanmış adam. Şu ormancıların hangisi davasına inanmamış ki... Yoksa bu kadar kırtasiye, bu kadar mücadele içinde çalışabilirler mi idi. Adam aç kalır da buna dayanamaz. Uyku yok, dünek yok. Üstelik de kötü adamsın. Partiler gelir çöker, politikacılar yüklenir, halk yüklenir. Şu iki cami arasında kalan var ya, tam ormancı..."

Öte yandan özellikle orman yangınları o dönemde de ormancıların çok yoğun ve yorucu çalışma koşullarına sahip olması sonucunu doğurmaktadır. İzmir Orman İşletme Müdürü Hakkı Özkan'ın sözleri durumu açıkça ortaya koymaktadir: ${ }^{17}$

"Yedi yıllık mühendisim. Yedi yılın yedi otuz Ağustosunda da bayram yapamadım. Yedisinde de köylüler tatilden istifade ederek yangın çıkardılar.”

Eserde bir orman dertlisi olarak belirtilen ve orman davalarına bakan bir avukatın ormancılar hakkındaki düşünceleri dönem ormancılarının orman sevdasının açık bir yansımasıdır: ${ }^{18}$

“... Orman davasını politika adamlarımız, münevverlerimiz bilmiyorlar. Bendeniz de bilmiyordum.

Tâ ki orman avukatı oluncaya kadar. On beş yıl orman avukatlığ yaptım. Işsin içine girince gördüm ki bu dava büyük davadır. Eskiden ormancıların telâşlarına, ormana verdikleri ehemmiyete, vatanla ağacı aynı ayarda tutuşlarına bakıyor da bu adamlara adeta klzıyordum. Sonra anladım ki iş başka... O gün bu gündür. Ben ă̆aç dostuyum ve muhitimde bunun mücadelesini yapıyorum..."

\subsection{Orman köyleri}

Yaşar Kemal röportajları yapmak için Anadolu'yu dolaşırken ormanlarla birlikte ormanların içinde ya da yakınında yaşayan halkı da gözlemleme fırsatı yakalar. Bu gözlemleriyle yaptığı saptamaları röportajlara da yansıtır. Orman köylülerinin durumu her açıdan çok kötüdür. Orman köylüleri topraksız, yoksul ve çaresizdir. Bu durum köylünün ormanla ilişkisinin yönünü şekillendiren temel etkendir. Geçinmesine yetecek kadar toprağ1 olmayan köylü için orman potansiyel tarım alanı, keçileri için de otlaktır. Bu durumun en açık ifadelerinden biri röportajlarda Süleyman Ağa olarak geçen bir köylünün sözlerinde yansır: ${ }^{19}$

"Keçi beslemek, açma açmak kolay mı sanırsın. Bilmeyene kolay görünür...

Bilmezler de vay köylü orman yakar, vay köylü ormanı keçisine yedirir. Bilmezler. Bilmezler de

\footnotetext{
${ }^{15}$ Bölüm 5- Ağaç Boğucuları ve Boğulan Ağaçlar, s. 33.

${ }^{16}$ Bölüm 16- Bitmez Tükenmez Davalar, s. 88-89.

${ }^{17}$ Bölüm 12- Sanki Çaresiz Dertler, s. 92.

18 Bölüm 15- Bir Orman Dertlisi, s. 83.

${ }^{19}$ Bölüm 10- Keçiye ve Açmaya Karşı, s.56-57.
} 
köylü keçiyi keyfinden besler sanırlar. Bilmezler de köylü canı sıkıldı̆̆ı için açma açar sanırlar. Ya ben aç kalacă̆ım, ya orman gidecek. Bunun ikisi ortası yok. Bu dağlarda keçiden başka hayvan iyi yetişmez. Bu dağların hayvanı keçidir. Ya keçi besleyeceğim, ya açlıktan öleceğim. Keçi de ormanını yiyecek devletin. Çare yok. Başka çare yok. Açma açacağım. Hükümet her ağacın başına bir bakım memuru dikse, her bakım memuruna da bin lira maaş bağlasa gene ăgacı boğup yakıp, kesip tarla yapacă̆ım. Başka çare yok. Ya açlıktan kıvranıp öleceğim. Ya da ormandan tarla yapacă̆ım. Hor görmeyin bizi. Bu dağlarda başka geçim yolu yok. Birincisi keçi, ikincisi tarla.”

Yazarın yangınla açılan bir tarlada çalışan ve adı Memed olarak geçen bir köylüyle diyaloğunun sonunda sorduğu "Yangını kim çıkarmış acaba?" sorusuna Memed'in verdiği yanıt hem köylünün durumunu hem de ormandan kazanılan tarım topraklarının önce verimli oluşunu, fakat zamanla yok olup gitmesini açıkça ortaya koymaktadir: ${ }^{20}$

"Kim çıkaracak? Tazı köylüler geçerken ateş atmış olacaklar. Allah razı olsun onlardan. Yoksa çoktan köyü bırakıp gitmiştik. Bir dönüm tarlamız bile kalmamıştı. Bütün toprağımızı yağmur taşıyıp götürmüştü. Bire bir bile alamıyorduk. Allah razı olsun yangıncıdan. Bir toprak çıktı ki ormandan bire beş, bire on veriyor."

Röportajlarda dikkat çeken bir diğer nokta da köylerin toplu köy yerine dağınık köy yapısı sergilemesidir. Hem köyleri oluşturan mahalleler hem de mahallelerdeki evler birbirine oldukça mesafelidir. Yazar bu durumu Düzağaç köyünü oluşturan 10 mahalleyi sıraladıktan sonra şu şekilde aktarmaktadır: ${ }^{21}$
“...Bu mahallelerin birbirine en yakını üç buçuk saat uzaklıkta. ${ }^{22}$ Mesela Düzağaçla Kırkkavak arası dört buçuk saat çekiyor. Karakanlarla Kırkkavak arası yedi saat... Mahallelerdeki her ev arası da yarım saat...”

Yaşar Kemal bir gazeteci gibi gözlem yapmakla kalmayıp bir bilim adamı gibi de gözlem yapmıştır. Antalya Beşkonak ile Isparta Sütcüler arasındaki on köyü on beş günde dolaşmış ve bu köylerin sosyo-ekonomik yapısını ortaya koymak için bir de anket yapmıştır. "Anketimin doğru olması için birçok insanla görüştüm. Yüzlerce kadın erkek.” demektedir yazar yayımladığı röportajlarda. Anket sonuçlarına göre de köylüleri fikara, orta halli ve zengin olarak üç gruba ayırır. F1kara olarak nitelendirdiği gruba örnek olarak Ramazan adlı bir köylünün durumunu detaylarıyla aktarır. Bu aktarımın önemli kısımlarını, yani Ramazan'ın sosyo-ekonomik durumunu ortaya koyan temel karakteristikleri şu şekilde özetlemek olanaklıdır: ${ }^{23}$

- Dört çocuklu,

- Eğimli arazide iki dönüm, taşlı ve verimsiz bir tarlası var, bire üç veriyor,

- Bu tarla yetmediği için ortakçı olarak da 12 dönüm tarla ekiyor,

- Keçisi yok, bir eşeği, bir ineği var,

- 400 lira borcu var, bankaya değil şahıslara, faizle ödüyor,

- Her yıl Manavgat'a inip amelelik yapıyor, bu yıl amelelikten 60 lira kazanmış,

- Evine sadece kurban bayramında et girmiş, bir de üç yıl evvelki kurban bayramında,

- Yılda üç kilo yă̆ yiyorlar,

- Çarşıdan elbiselik, çamaşırlık almıyorlar. Kendileri dokuyorlar. Karısı ve çocuklarının hiç ayakkabısı olmamış. Kendinin de ayağında keçi derisinden bir ham çarık var,

- Hiç gazyağı yakmamış, evi çırayla ısıtmış,

- Evine tatlı olarak geçen yıl yarım kilo bal girmiş, onu da bal satan biriyle buğday takasıyla almış,

- Bütün derdi ormancıları atlatıp birkaç dönüm tarla açabilmek,

- Evindeki eşyalar; iki yatak eskisi, birkaç bakır sahan, bir tencere, bir testi.

Köylünün durumu o kadar kötüdür ki, röportaj yapılan köylülerden biri olan Abdış Ağa bir gün valiye elli beş yıllık hayatının yalnızca beş yılında yaşadığını, gerisini ise ömürden saymadığını; yaşadığı beş yılın ikisinin askercilikte, üçünün de İzmir mapushanesinde geçtiğini söylediğini anlatır yazara. ${ }^{24}$ Abdış Ağa aynı bölümde köylerinin ormanlık, yayla savı bir yerde olduğu için sıtma savaşının dışında tutulduğunu ancak köylerinde sıtma

\footnotetext{
${ }^{20}$ Bölüm 9- Orman Yangınlarının Sebepleri, s.51.

${ }^{21}$ Bölüm 7- Orman İçinde Yaşayanlar, s.41.

${ }^{22}$ Uzaklıklar yürüme süresi olarak belirtilmiştir.

${ }^{23}$ Bölüm 7- Orman İçinde Yaşayanlar, s.42-43.

${ }^{24}$ Bölüm 4- Dağların Onmazları, s.30-31.
} 
da görüldüğünü anlatır.

Yoksulluk ve topraksızlık köylüyü ormana yöneltir. Ekilen tarlalar yetersiz gelmeye başladıkça ormandan yeni tarlalar açmak çözüm olarak görünür. Buna rağmen köylüler bunun kalıcı çözüm olmadığının da bilincindedirler. İsmail Efendi durumu şöyle anlatır: ${ }^{25}$

“...Bak Bey, Allahaşkına iyi bak! Burada tarla olur mu? Bu yamaçta tarla olur mu? Buraya eksen eksen bir yıl ekebilirsin. Sonra sel gelir topră̆g alır gider. Dĕ̆ger mi?...”

Diğer yandan köylerde yoksulluğa ve orman tahribine çözüm konusunda oldukça ileri görüşlü fikirleri savunanlar da bulunmaktadır. Bunlardan bir tanesi röportajlarda Babacık olarak geçmektedir. Babacığın köylünün kalkınmasına ilişkin iki temel yaklaşımı bulunmaktadır. Birincisi alternatif gelir kaynağı yaratmak, diğeri de köylerin dağlardan alçak bölgeler taşınması. Babacık bu konudaki düşüncelerini şu şekilde dile getirmektedir: ${ }^{26}$

“...Hükümet keçiyi ve ekini yasak etsin. Bize de tezgah ve iplik göndersin. Iyi bez dokumasinı gösterecek ustalar göndersin. Köylüye belletsinler. Bir de yol yaptırsın. Bezleri satarız. Bizi bol bol geçindirir her yılki dokuduğumuz bez...”

“...Bizi buralardan kaldırmaktan başka çare yok. On yıl sonra ormanı bitecek... Ormanlar bittikten, tarlalar taşındıktan sonra gene başına bela olacă̆ız hükümetin ... Türkiyemizde boş yer mi yok. Bizi oralara iskan etsin...”

Köylüler arasında ormanların köylüye zimmetlenmesi olarak özetlenebilecek görüşleri savunanlar da bulunmaktadır. Bunlardan biri olan Abdurrahman Uzun bu görüşü şu şekilde dile getirmektedir: ${ }^{i}$

“...Bizim köy kaç hane, kırk beş hane. Köy hudutları içinde ne kadar orman var, şu kadar. Ölçersin ormanı, kırk beş parçaya ayırır köylüye teslim edersin. Her köylüden kendisine teslim edilen ormanı istersin. Vermediler mi, bir ă̆aç mı kesilmiş gel beri ă̆am, gel beri dersin... Amma ona önce zati ihtiyacı olan ormanı, keresteyi verirsin tabii...”

Bu görüşe köylülerden karşı çıkışlar da görülmektedir. Herkesin birbirinin ormanına zarar verme olasılı̆̆g karşı çıkış gerekçelerinden biridir. Diğeri de herkesin kendisine verilen ormanı yavaş yavaş tarlaya dönüştürme öngörüsü.

\subsection{Orman yangınları}

Röportajların ana konusu olan orman yangınları pek çok yerde temel nedenleriyle birlikte dile getirilmektedir. Yangınlar hakkında açıklayıcı teknik bilgiler de bolca yer almaktadır. Örneğin bir orman işletme müdürünün ağzından aktarılan şu sözler rüzgarın orman yangınları üzerindeki etkisini açıkça ortaya koymaktadır: ${ }^{27}$

“... Bir türlü söndüremezsin. Bin kişi bile olsan söndüremezsin. Ormanın içinde kıvrıla kıvrlla akar gider. Dolanır durur. Harman gibi yananın etrafinı iyice açtın mı tamam. Zor atlar. Söner kalır olduğu yerde. Ama benim bu rüzgarda hiç umudum yok. Söndüremeyeceğiz. Koca dă̆ yanacak. Hay be anasını. Işte böyle. İste böyle böyle memleket yanıyor. Bir memleket yanıyor, biz seyirci kalıyor."

Görüldüğü gibi bu satırlarda hem rüzgarın orman yangınını hızlandırıcı ve söndürmeyi zorlaştırıcı etkisinden bahsedilirken hem de yangının söndürülmesinin mümkün olmadığına değinilmekte ve ormancının çaresizliği vurgulanmaktadır.

Bir noktada yazar ormancılarla birlikte bir yangına müdahale ettikleri anı anlattığı kısımda şöyle söylemektedir: ${ }^{28}$

"Makinayı dă̆ın yamacına sürdük. Oralarda bir yerlerde bırakıp tırmıkları aldık. Tırmıklar demirdendir. Topraktaki dökülmüş kuru yaprakları alırlar. Kuru yapraklar alınınca ateş atlayamaz."

Yine aynı bölümde (s.9) orman yangını türleri hakkında bilgi verilmektedir. Üç türlü yangın olduğu, bunların dip,

\footnotetext{
${ }^{25}$ Bölüm 5- Ağaç Boğucular ve Boğulan Ağaçlar, s. 36.

${ }^{26}$ Bölüm 11- Ormanı Bizden Değil Bizi Ormandan Kurtarın, s.63 ve s.65.

${ }^{27}$ Bölüm 1-Ormancılar ve Orman Yangınları, s.8-9.

${ }^{28}$ Bölüm 1- Ormancilar ve Orman Yangınları, s.9.
} 
gövde ve baş yangını olarak adlandırıldığı; en çok görülenin dip yangını olduğu vurgulanıp, dip yangının çıkış ve seyri ile ilgili bilgiler aktarılmaktadır.

Eserde orman yangınlarının nedenleri de açıkça vurgulanmaktadır. Aslında Yaşar Kemal pek çok köylüye ormanı neden yaktıklarını sormuş ama hiçbir köylü ormanı yaktıklarını kabul etmemiş, yakılıyorsa da civardaki diğer köylerde yaşayan köylülerin yaktığını iddia etmişlerdir. Köylülerin bu konudaki yaklaşımlarına örnek olarak şu satırlar gösterilebilir. İbrahim Emmi anlatıyor: ${ }^{29}$

“...Köylü orman yakmaz. Ne desin de yaksın. Hazreti Peygamberimizin beşiği, evimizin eşiği ă̆aç. Ă̆aç yakılır mı? Alimallah adamın eli kurur. Ağaç gibi var mı kardaş, kırmızı gül de ă̆açtandır. Biz ağacın kıymetini biliriz. Köylü hiç ağaç yakar mı kardaşım. Efendi bilâderim.

"Bizim köylüler orman yakmasını bilmez ki sebebini bilsin. Orman yakmak vatanı yakmak demektir. Düzağaçlılar ormanın klymetini bilir...”

Fakat Düzağaç köyünde de benzer cevaplardan sonra, komşu köylüler suçlanarak da olsa köylünün orman yaktığ1 itiraf edilir: ${ }^{30}$

"Bozlar yakar ormanı, Tazılar, Bozyakalılar, Bolasanlılar yakar ormanı. Düzağaçlıların elinden gelse ağaç dikecek dağlara."

Yazar köylülerden ormanın neden yakıldığına dair bilgi alamamaktan dolayı çaresiz hissettiği bir anda ona kılavuzluk yapan bir köylü, Mustuk dayanamayıp anlatmaya başlar: ${ }^{31}$

"Sana söyleyeyim. Teker teker söyleyeyim Efendi. Neden orman yakarlar? Tarla açmak için bir. Tarlanın etrafi ormanlık olur. İçinde kara böcük saklanır. (Domuz) Kara böcük çok zarar verir mahsüle. Çok olur öldüremezler. Onun için tarlanın yakınındaki ormanı yakarlar, iki. Bir de yanmıs orman toprağında o yll bir ot biter ki diz boyu. Keçiler o otları yeyince çok etlenirler. Bir de ormandaki keneler vardır. Keneler yansın diye ormanı yakarlar, bu üç. Bir de tahtactlar işsiz kalırlar. Orman dairesi onlara orman gösteremez. IŞ bulmak için yakarlar, bu dört. Bir de orman memurlarına kizar köylü. Yani zulüm gören köylü. Mahkemeye verilen köylü... bu beş. Bir de köyde iki adam birbirine hasim olur. Biri, ötekinin tarlasindan ormana ateş verir ki tarla sahibini orman dairesi tutsun da mahkemeye versin. Süründürsün, bu alt. Daha bir ay evvel böyle bir adam yakalandı. Bolasan muhtarına kızmıs adam, muhtarın tarlasından ormana ateş vermiş. Muhtarı yakalamışlar. Muhtar kendisinin değil de, ormanı düşmanın yaktığını isbat etmiş. Adam şimdi hapiste. Şimdi anladın mi sebeplerini? Söyledim mi sana?..."

Ormancıya kızgınlık nedeniyle orman yakmaya örnek oluşturacak olaylar da eserde yer almaktadır. Abdurrahman Uzun adlı bir köylü, orman yangınlarıyla canını dişine takarak mücadele eden bir bakım memuru (orman muhafaza memuru)'ndan ve o yangına gittiğinde onun evinin yakınındaki ormanı ateşe veren köylülerden bahsetmektedir. Abdurrahman Uzun’a göre çıkan yangını yine memura acıyan köylü söndürmüştür. ${ }^{32}$

Orman yangınlarının önemli nedenlerinden biri olarak da 1937 yılından önce orman işletmeciliği yapan müteahhitler gösterilmektedir eserde. Devlet orman işletmeciliğine geçildikten sonra müteahhitlerin odun ticareti yapmak için bu yolu kullandıklarını Ali Çavuş olarak geçen bir tahtacı şöyle anlatıyor: ${ }^{33}$

"1937'den önce Orman işletmeciliği yoktu. Ondan önce Devlet dikili olarak ormanı müteahhide satardl. Müteahhid de bizleri iş̧̧i olarak tutardl. Müteahhidler o zamanlar bir bölgenin bütün ormanlarını satın alırdı. Mesela bu bölgeyi ...oğulları almışlardı. On beş yıl bu ormanları kestiler. Bütün bu dağlarl gezdim diyorsun, doğru dürüst bir ağaç gördün mü? ...oğulları tüm ağaçları dipten tıraş ettiler... Bazan ormanlar yantyor. Kalıntıları işlemek gerekiyor. O zaman bir ormanı bir ucdan bir uca işliyoruz. Ne dağlardan indirmek, ne de ă̆aç ağaç kereste seçmek var... Bir de yangınların çoğunu bizim üstümüze atarlar. Bizim geçimimiz orman üstüne. Biz orman yakar mıyız? Güya kolay iş bulalım diye ormanı yakıyormuşuz. Haşa! Onu müteahhitler yaktırtyorlar. Biz de

\footnotetext{
${ }^{29}$ Bölüm 2-İnsan ve Orman, s. 17-18.

${ }^{30}$ Bölüm9- Orman Yangınlarının Sebepleri, s.49-50.

${ }^{31}$ Bölüm 9- Orman Yangınlarının Sebepleri, s.52-53.

32 Bölüm 11- Ormanı Bizden Değil Bizi Ormandan Kurtarın, s.60-61.

${ }^{33}$ Bölüm 14- Tahtacılar, s. 78-79.
} 
işliyoruz."

Bir yangın sırasında rapor vermek için orman işletme müdürünün yanına gelen orman işletme şefinin şu sözleri yangınların sırrını bütün açıklığıyla ortaya koyuyor: ${ }^{34}$

"Yangın büyük değildi. Çabuk söndürüyorduk. Söndürüyorduk ama, arkamızı dönünce gene yaklyorlardı. Sabaha kadar biz söndürdük, onlar yaktılar. Sabah oldu."

Bir yangın sırasında orman işletme müdürü köylüleri toplasın diye bakım memurunu (orman muhafaza memuru) gönderir. Bakım memuru çok az sayıda köylüyle döner ve ne yaptıysa köylüyü ikna edemediğini anlatır. Bunun üzerine Yazar müdürden izin alarak köylü toplamak için şansını denemek ister. $\mathrm{O}$ da başarılı olamaz. Bir köylünün ona söylediği ve röportajlarda yer alan cevap da orman yangınlarıyla köylüler arasındaki ilişkinin bir diğer boyutunu ortaya koymaktadır: ${ }^{35}$

"Bize suç bulma ă̆am. Bu her gün böyle. Canımızdan bezdik. Şu ormanlar yanıp bitse de tüm, kurtulsak... Ü̧̧ aydır hep böyleyiz. Gelirler uykumuzu bölerler. Her Allahın gecesi. Gece yok gündüz yok. Biz işi gücü biraktık. Ormanla uğraşlyoruz. Bitse de kurtulsak. Ne kaldı zaten ya ..."

\subsection{Açmacılık}

Yanan Ormanlarda 50 Gün, ormanların açılarak tarla yapılması olarak tanımlanabilecek açmacılık açısından da çok değerli bilgiler içermektedir. Özellikle açmacıllğın nedenleri ve orman açmak için uygulanan yöntemler eserde bolca ve tüm açıklığıyla yer almaktadır. Açmacılığın nedenleri genel olarak köylünün içinde bulunduğu sosyo-ekonomik koşullardır ve bu konu hakkında yukarıdaki bölümlerde açıklamalar yapılmıştır. Köylü açmacılığı adeta bir kurutuluş veya var olma mücadelesi olarak görmektedir. Yazarın detaylı görüşme yapıp sosyo-ekonomik yapısını ayrıntılı olarak ortaya koyduğu ve orta halli olarak tanımladığı Ali Gülmez'in şu sözleri konunun bu boyutunu açıkça ortaya koymaktadır: ${ }^{36}$

"Çocuklar bir büyüsün, işe elleri yetecek kadar olsun hele. Ben mahpusa girince aç kalmayacak hale gelsinler... Bir çok tarla açacağım, bir çok tarla açacağım ki ormandan... Paydos fikaralığa gayrik... Atarlar hapse. Yatar, çıkar gene açarım. Gene gene açarım. Hele bir büyüsün çocuklar."

Açmacılığın pek bilinmeyen yöntemlerinden biri boğmadır. Boğma yöntemi İsmail Efendi’nin ağzından şöyle aktarllır: ${ }^{37}$

"Baltayı alır eline... Aldımı baltayı eline, kabuğu firdolayı keser. Dört parmak. Bir daire gibi kabuğu çıkarır. İçinin yalabuğunu güzelce yer. Sonra efendim öteki ağaca geçer. Onu da öyle yapar.

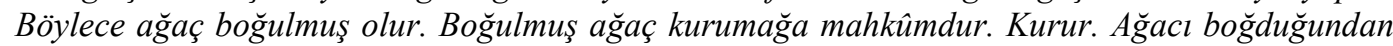
dolayı adamı yakalasan bile, mahkemeye versen bile ceza görmez. Ăgacı boğmak, tahribat sayılmaz... İki yll sonra ağaçlar çürür. Çürümeyenleri adam kökler, odun yapar. Sonra da orayı tarla yapar. Şu gördüğ̈̈n tarlaların hepsi boğulmus ağaç tarlasıdır. Şu gördüğ̈̈n göz alabildiğine uzanan kıraç, sel yeniği topraklarda, toprak denmez gayri onlara ya, kayalıklarda boğulmuş ormanlardan çıkarılmış eski tarlalardır. Onlar artık işe yaramaz. İki yıl sonra bu tarlalar da işe yaramayacaktır."

Görüldüğü gibi bu sözlerde hem boğma yoluyla açmacıllğı̆n nasıl gerçekleştiği anlatılırken hem de açılan tarlalardaki toprakların taşınıp iki yıl sonra işe yaramayacağının köylü tarafından da biliniyor olduğunu gözler önüne sermektedir. Önemli bir diğer konu da Orman Yasası'nca suç olarak tanımlanmayan kabuk soyma, yani boğma yönteminin köylü tarafından nasıl kullanıldığının ortaya konulmasıdır.

Bir diğer açma yöntemi ormanın yakılmasıdır. Bununla ilgili olarak yine Ali Gülmez'in ağzından aktarılanlara göz atmakta yarar var: ${ }^{38}$

"Bundan beş yıl önce Bozlar köyü ormanlarında bir yangın çıktı. Tam on beş gün geceli gündüzlü devam etti. Ormanlar yandı kül oldu. Bir tek dikili ağaç bile kalmadı. Ağaçların kökleri bile yandı

\footnotetext{
${ }^{34}$ Bölüm 1- Ormancılar ve Orman Yangınları, s.13.

${ }^{35}$ Bölüm 1- Ormancılar ve Orman Yangınları, s.10.

${ }^{36}$ Bölüm 7- Orman İçinde Yaşayanlar, s. 43-44.

${ }^{37}$ Bölüm 5- Ağaç Boğucuları ve Boğulan Ağaçlar, s. 35.

${ }^{38}$ Bölüm 8- Yanan Ormanların Yerinde Eşinenler, s. 47-48.
} 
dersem inan... Bir tarla açtılar, bir tarla açtılar... Koyaklardan yamaçlardan, pınar yanlarından bir tarla açtılar... Her birisinin yirmi dönümlük tarlası oldu en az... Bir de kara toprak çıktı ışıl ışıl... Ekmek yerine toprağı ye... Bozlarlı o gün bugündür buğday satar. İyi bakarlarsa toprak beş on yıl daha dayanır. Yamaçlar çok dik değil Bozlarda. O yüzden yă̆mur, sel toprağı ancak beş on yılda yıkayabilir. Ondan sonra da Allah kerim. Bozlar bir orman daha yakarlar. Şimdi gel de sen ormanı yakma. Ormanı tarla etme."

Ormandan tarla açmak amacıyla yaygın olarak kullanılan bir diğer yöntem ise ağaçların kesilmesidir. Yaşar Kemal bu yönteme ilişkin gözlemlerini bir örnek olay üzerinden şu şekilde aktarmaktadır: ${ }^{39}$

“... Taşlı tarla Hasan Korkutur adlı birininmiş. Bundan üç yıl önce bir dönümmüş tarlası. Şimdi altı. Geçen yılda kırk çam doğrayıp üç dönümlük bir tarla daha katmış tarlasına... Orman dairesi onu mahkemeye vermiş bu yüzden. Bir hafta hapislikle 1254 lira para cezasina mahkum olmuş Hasan. Hasan bir hafta hapsini yattıktan sonra ortadan kaybolmuş. O gün bu gündür Hasan Korkuturdan haber yok. Hasanın üç çocuğuyla karısı ellerin aralığında kalmış. Köylü de imdatlarına yetişmeseymiş açlarından öleceklermiş. Bereket ki köylüye, tarlasını ekip biçmişler de... Bu dağlarda binlerce Hasan Korkutur misali var."

Yaşar Kemal bütün gözlemlerinin sonucunda, açmacılıkla ilgili oldukça sağlıklı bir saptama yapmaktadır. Ona göre açmacılık yoluyla elde edilen tarım arazileri köylünün dertlerinin çaresi değildir. Yazarın kendi sözlerine bakalım: ${ }^{40}$

“Röportajlarımızda daha önce de gördük ki tarla açmacılık da orman tahribinde büyük rol oynuyor. Bunu türlü misallerle, türlü yaşayış tarzlarıyla gösterdik. Köylü orman sahalarını daraltarak, ziraat sahası açmaktadır. Gördük ki ormandan açılan ziraat sahaları ormana ${ }^{41}$ elverişli değildir. Açılan tarlaların ömrü en çok üç yıldır."

\subsection{Orman işletmeciliği}

Yaşar Kemal'in röportajları yaptığı dönem 1950'lerin ilk yarısıdır. 1937 yılına kadar Cumhuriyet orman işletmeciliği açısından Osmanlı Devleti'nden kalan yasa ve uygulamayı sürdürmüştür. 1870 yılında çıkarılmış olan ve 1937 yılında çıkarılan 3116 Sayılı Orman Kanunu'na kadar uygulanan Orman Nizamnamesi orman işletmeciliği açısından müteahhitlik usulünü, yani ormanların, ihale yoluyla işletmecilik hakkını kazanan müteahhitler tarafından işletilmesini benimsemiştir. 3116 Sayılı Yasa ise bunun yerine devlet orman işletmeciliğ ilkesine dayanmaktadır. Bu nedenle devlet orman işletmeleri kurulmaya ve yurt sathında örgütlenmeye başlamıştır. Eserde bu konuya ilişkin bilgiler de yer almaktadır. Orman yangınları bölümünde aktarılan Ali Çavuş'un sözleri bu bilgilere örnek olarak gösterilebilir. Ali Çavuş'un sözlerinin devamı şu şekildedir: ${ }^{42}$

“1937'den, yani Devlet Orman İşletmesi kurulmadan önce müteahhitler ormanı insaf etmeden tıraş etmişler. Yangınlardan önce güney ormanlarını müteahhitler bitirmişler. Ve Suriyeye satmışlar. Mısıra satmışlar. Bütün Araplar yıllarca güney ormanlarını haraç mezat kullanmışlar. Bir rivayete göre Süveyş kanalının kereste ihtiyacı Güney ormanlarımızdan temin edilmiş. Ve efendim bu sebepten güneyde orman kalmamış. El elde, baş başta!...

“Devlet İ̧sletmeleri 1945 yılında teşkilâtını tamamlamış... O zaman kadar da türlü dalavereler dönmüş ve ormanlarımızı su gibi Suriyeye akmış. 1945 'ten sonradır ki doğru dürüst, ilmî şekilde bir kesim yapılmă̆a başlanmış..."

Yazarın röportajlar sırasında tanışıp bilgi aldığı, adı verilmeyen ve orman davalarına bakan bir avukatın sözleri ise müteahhitler eliyle yapılan orman işletmeciliğinin sakıncalarını ve devlet orman işletmeciliğine geçildikten sonra bu müteahhitlerin kaçakçılık yapmaya başladıklarını ortaya koymaktadır: ${ }^{43}$

“Büyük, zengin orman müteahhitleri vardı. 1937'den önce ormanları dikili olarak devletten alırlar, işler satarlardl. Güneyde bu büyük işti. Çok para getiriyordu. Ăgacın metreküpünü inanılmayacak

\footnotetext{
${ }^{39}$ Bölüm 8- Yanan Ormanların Yerinde Eșinenler, s. 48.

${ }^{40}$ Bölüm 13- Orman Dertlerinin Biricik Çaresi, s. 97.

${ }^{41}$ Kitapta ormana deniliyor olmasına rağmen tarıma olması gerekir. Baskı hatası olduğu düşünülmektedir.

42 Bölüm 14- Tahtacılar, s. 79-80.

${ }^{43}$ Bölüm 15- Bir Orman Dertlisi, s. 84.
} 
kadar ucuza satın alıyor, otuz kırk misli pahalıya satıyorlardı. 1945 yılında Orman işletmeleri teşkilatını kurup da işe başlayınca müteahhitlerin işleri suya düştü. Açıkta kaldılar, işleri öldü. Bunun üstüne onların da çokları kaçakçılık yaptılar. Böylece, bin türlü hilelerle işlerini devam ettirdiler."

\subsection{Tapulu kesimler}

Yanan Ormanlarda 50 Gün hem Türkiye ormancılık tarihi açısından hem de ormancılık politikası açısından son derece önemli bir olaya, tapulu kesimlere 1şık tutacak bilgiler içermektedir. Tapulu kesim teknik olarak orman sayılmayan sahipli arazilerdeki ağaçların kesilmesine ilişkin uygulamalara verilen genel bir addır.

Eserde aktarılan bilgiler o dönemde tapulu kesimlerin büyük bir kaçakçılık sistemine dönüştüğünü göstermektedir. 3116 sayılı Orman Kanunu’nun ormanı tanımlayan birinci maddesinde 1950 yılında değişiklik yapılarak, sahipli arazide bulunan ve 3 hektardan (30 dönüm) küçük alana sahip ağaçlık alanlar orman tanımı dışarısına çıkarılmış; dolayısıyla tapulu kesime konu alanlar haline gelmiştir. Bu alanlarda oluşan kaçakçılık sistemini eserde adı verilmeyen aynı avukat şu şekilde aktarmaktadır (41 numaralı dipnotun devamı şeklinde): ${ }^{44}$

“... 1950de 5653 sayılı kanunun yanlış anlaşılmasından dolayı müteahhitler tekrar sahneye çıktılar.

Fırsat bu firsattır diye başladılar işe.

“Müteahhitler köylülerden tapu, tapularının içindeki ă̆açları satın almağa başladılar. Üçer, dörder dönümlük, hudutlarl gayrimuayyen tapular aldılar... Eski tapularda dönüm nazara alınmaz, tapu hudutları nazarı itibara alınır. Meselâ tapuda on beş dönüm yazılı bir tarlanın hudutları içine on bin dönüm, hattâ yüz bin dönüm de girebilir. Anadoluda halen beş dönümlük bir tapuyla otuz bin dönümlük tarlaya sahiplenmiş kimseler çoktur. Tapuların yüzde doksan sekizi böyledir. Iş̧te bu müteahhid allem etmiş, kallem etmiş on yedi dönümlük tapusu içine yüz bin dönümlük bir sahayı almış. Alış tarzı da dikkate değer. Tapuda şöyle hudutlar var: Cenuben Emine kızın gelin olduğu yer, limalen yanık çınarın kökü, garben kan mezarı, şarkan pınar. Görülüyor ki yukarıdaki hudutlar muayyen değildir. Pınar, her yerde pınar vardır. Emine kı nerede gelin olmuştur, Allah bilir onun orasını... Bilirkişiler nerede derse orada gelin olmuştur...

"Bu şekilde daleveralarla efendim, yüzbinlerce metreküp orman kesilip yok edilmiştir. Ormancllar bunu kabul etmiş midir? Hayır. Onlar da mücadele etmişlerdir bununla. Bu ağaçları kesenler mahkemeye verilmiştir. Bunlardan bir tanesi dört milyon liralık ăgaç kesmesinden dolayı mahkemede iken af çıkmıştır. Bir de bunlar için hususi af kanunu çıkarılmıştır. Müteahhitlerimizi korumalıyı efendim. Toprak gider efendim, müteahhitlerimiz kalır. Bir fincan kahvenin bir yıl hatırı var...”

Yaşar Kemal, eserde avukatın sözlerini aktardıktan hemen sonra kendi yorumunu da katarak ek bilgiler vermektedir:

“Avukat dertli adam, aşk adamı, dürüst adam. Bir fincan kahvenin kırk yıl hatırı olmaz olsun. O değil mi belimizi büken.

"Manavgat, Elmall, Kaş, Fethiye, Silifke ve daha birçok ormanlarımızı bu tapulu kesim yok etmiş. Bereket versin ki kırk yıllık kahvenin hatırı o kadar uzun sürmeyip 5653 sayılı kanun için sonradan bir izahname gönderilmiş de durum kurtraılmış.

“Şu orman üzerinde nice menfaatler dönmüş. İnanılmaz. Veyl saf olanlara..."

Ne var ki tapulu kesimlerin köylü açısından algılanış şekli ise bütünüyle farklıdır. Yine Karacasu'da bir köylü kendi bakış açısını şu şekilde aktarmaktadır: ${ }^{45}$

"Bakın burada hiç mi hiç yangın olmaz. Yıllardır yangın kazara bile çıkmamıştır. Çünki orman tapuludur. Bir gün gelecek ki, köylü ormanını alacak umudunda... Sonra bir orman tahdit komisyonu geldi. Işsleri o berbat etti işte... A Ğaçları zamanla tıraşlanmış tarlaları sahiplerine verdi de ă̆açlıklı tarlaları orman saydı. Köylüler de ne yaptılar bu sefer... Tarlalarındaki ă̆açları

${ }^{44}$ Bölüm 15- Bir Orman Dertlisi, s. 84-85.

${ }^{45}$ Bölüm 16- Bitmez, Tükenmez Davalar, s. 89-90. 
tüccarlara meccanen verdiler. Sırf tarlalarındaki ă̆açlar yok edilsin diye... Tüccarlar ormanları kestiler kestiler gittiler, köylüler suçlu olarak mahkemelere verildiler..."

Yanan Ormanlarda 50 Gün'ün 13. bölümü “Tapulu Kesimler” başlığını taşımaktadır. Bu bölümde yazarın baştan sona şahit olduğu bir tapulu kesim anlatılmaktadır. Olay Antalya Akseki'de geçmektedir. Yazar orman işletme müdürü Lütfi Yıldırım'ın odasındayken Akseki'deki bir tapulu alanda yapılacak ağaç kesimi için başvuruya gelenler olur. Gelenlerden biri Antalya, diğeri Konya eski milletvekilidir. Akseki’nin Aşağı Işıklar köyünden İbrahim Efendi'nin tapulu arazisindeki 50 civarında çam ağacının kesim talebini Konya milletvekili sözlü olarak iletir. Konya milletvekili Konya'da kerestecilik yaptığını ve bu köylünün ağaçlarını kıymetlendirerek ona yardımcı olmaya çalıştığını söyler. Orman işletme müdürü Lütfi Yıldırım keşif yapıp Umum Müdürlüğe yazacaklarını ve oradan gelecek yanıta göre işlem yapacaklarını söyler. Eski Konya milletvekili işlemin bir an önce bitmesi için özel olarak rica eder, Antalya milletvekili de bu ricayı destekler. Özellikle eski Konya milletvekili amaçlarının köylüye yardımcı olmak olduğunu üstüne basarak vurgular. Misafirler gittikten sonra Lütfi Yıldırım işin aslını yazara şöyle anlatır: ${ }^{46}$

“Size bunun aslını astarını söyleyeyim. Bütün işimiz gücümüz böyle şeylerle uğraşmak. Gece gündüz tapulu keşfine git. Bütün ormanlar tapulu gibi bir şey. Nereye elini uzatsan bir tapu çıkıyor. Bunların dedikleri yerin tapusu da dört beş yıl önce alınmıştır.

"Bu tapular şöyle alınıyor: Tarla sahibi olduğunu iddia eden kişi mahkemeye başvurarak, filan hudutlar içindeki tarlayı otuz yıldan beri ekip biçtiğini, ondan önce de dedesinin ekip biçtiğini, tarlanın tapusunun kendisine verilmesini istiyor. Mahkeme keşfe gidip, bilirkişilere soruyor ve tarlanın tapusunu o kişiye veriyor. Ve tarla da içindeki ormanla birlikte o kimsenin oluyor. İşte bu yüzdendir köylülerle ormancılar arasında bir dava, bir geçimsizliktir başlıyor."

Yazar işletme müdürünün izniyle birkaç gün sonra yapılan keşfe de katılır ve orada yaşananları aktarır. Bütünüyle teknik bir işlem olan keşfe Akseki Kaymakamı ile Demokrat Parti Genel Meclis azalarından biri de katılmıştır. Eserde bu durum yorumlanmamış olmasına karşın bu katılımın keşfi etkilemek amacıyla olduğunu tahmin etmek zor olmayacaktır. Yaşar Kemal tarlanın içinde "kocaman kocaman ve düzgün” diye nitelediği seksen kadar ağacın olduğunu yazmaktadır. Keşif sırasında bilirkişilerden biri ile orman işletme müdürü arasında yaşanan şu diyalog oldukça aydınlatıcı niteliktedir (sırasıyla önce müdür, daha sonra bilirkişi düzeninde): ${ }^{47}$

"Hudut bu kayaya kadar mı, kayanın ötesine de geçer mi?"

"Geçmez."

"Şu çamlar bu tarafta mı kalır, öte tarafta mı?"

"Bu tarafta..."

"Bu kayalar dededen mi kalma?"

"Öyle."

“Bu kayalığl eker miydi dede?”

"Ekerdi."

"Kayalık ekilir mi?"

Bilirkişi susar. Müdür devam eder:

"Kayalı̆̆a tarla denir mi?"

"Madem ki hududu içinde, denir."

Orman İşletme Müdürü bilirkişilerle konuşurken orman işletme şefi de tarlayı ölçmektedir. Tarla yedi dönüm çıkar. Tapuda dört dönüm yazmaktadır. Müdür tapuda yazan kadar tarla gösterilmesini ister ama nereden nasıl ölçülürse ölçülsün dört dönümlük bir tarla bulamazlar. Bu şekilde zabıt tutulur ve keşif biter. Yaşar Kemal bu bölümü şu sözlerle kapatmaktadır: ${ }^{48}$

$$
\text { “Acaba o ulu çam ăgaçlarının katline ferman verildi mi?” }
$$

Yazar "Bitmez, Tükenmez Davalar" adını taşıyan 16. bölümde bir başka usulsüz kesim yöntemini de yine kendisine bilgi veren avukattan öğrendikleriyle aktarmaktadır. Tapulu bir arazide kim tarafından yapıldığı

\footnotetext{
${ }^{46}$ Bölüm 13- Tapulu Kesimler, s. 73-74.

${ }^{47}$ Bölüm 13- Tapulu Kesimler, s. 75.

${ }^{48}$ Bölüm 13- Tapulu Kesim, s. 76.
} 
bilinmeyecek şekilde ağaçlar kesilmektedir. Arazi sahibi mahkemeye başvurarak, arazisindeki ağaçların kimliği meçhul kişilerce kesildiğini, orman dairesinin ağaçları zaptederek satmak isteyeceğini belirterek ihtiyati tedbir talep eder. İhtiyati tedbir üzerine ağaçlar açık artırmayla satışa çıkarılır. Arazi sahibi, onun bir akrabası veya bir tüccar rakipsiz olarak açık artırmaya girer ve yok pahasına ağaçları satın alır.

Yaşar Kemal daha sonra orman dairesinin bu oyunu bozmak için açık artırmaya girerek ağaçları satın almaya başladığını ve böylelikle bu oyunu bir ölçüde bozduğunu belirtmektedir. Ancak avukat yazar kadar umutlu değildir ve ona şöyle der: ${ }^{49}$

"Yakında buna da bir çare bulacaklar."

Yaşar Kemal şu sözlerle konunun özünü ortaya koymaktadır:

"Ben bir tanesini söyledim. Daha öyle tahrip usulleri var ki, akıl sır ermez. Öyle yol buluyorlar ki şu keresteciler, şaşıp kalırsın. Mademki elinde tapusu var. Geri dur orman dairesi...”

\subsection{Diğerleri}

Yanan Ormanlarda 50 Gün adlı röportajlarda yukarıda açıklananların dışında ormancılık tarihi açısından anlam taşıyan ve günümüze, hatta geleceğe de 1şık tutan başka pek çok bilgi yer almaktadır. Bunlar aşağıda kısaca sıralanmıştır:

a. O dönem orman-halk ilişkilerinin sorunlu olduğu görülmektedir. Ormancılık örgütünün halk1 bilgilendirmek ve orman-halk ilişkilerini düzenlemek amacıyla yaptığı bazı halkla ilişkiler çalışmalarına eserde rastlanmaktadır. Örneğin, yazar “Antalya Orman Baş Müdürlüğ̈̈ her kayaya, her ăgaca, ormana, yollara orman sevgisi aşılayan vecizeler yazdırmış. Çıplak yamaçlara çimentoyla tâ uzaklardan görünen -Ormanı Koru!-lar kondurmuş. Kim anlar, kim dinler mi diyeceksiniz. Olsun. Mutlak faydası vardır. Tebrik ederim." 50 demek yoluyla bugün de devam eden bu uygulamaların ormancılık örgütünün, daha doğrusu devlet orman işletmeciliğinin ilk dönemlerinden itibaren yapıldığını ortaya koymaktadır.

b. Halk ve özellikle orman köylüleri orman yakmak, ağaç kesmek, ağaç boğmak, tarla açmak vb. suçlarla sık sık yargılanmaktadır. Örneğin yazarın köylülerin sosyo-ekonomik yapısını ortaya koymak amacıyla ayrıntılı olarak analiz ettiği hanelerden biri olan ve zengin haneyi temsil eden İmam Cemal Güvener hakkındaki şu açıklaması dikkate değer niteliktedir:"51 "Sonra yüz yirmi evlik Düzăgaç köyünün orman suçundan mahkemeye verilmemiş tek adamı. Yalnız Düzăgaç köyünün orman suçundan mahkemeye verilmemiş tek adamı değil, bu dăgların orman suçundan mahkemeye verilmemiş tek adamı ...” Bu durum köylülerde savunma yapmak amacıyla da olsa bazı temel bilgilerin yerleşmiş olması sonucunu doğurmaktadır. Örneğin yazar eserde Babacık olarak geçen kişiyle sohbetinde İbrahim Emmi adlı köylünün ormanlarla ilgili söylediği çok sayıda vecizeyi hatırlatarak, bunun nedenini sorar. Babacığın yanıtı şu şekildedir: “... O, çok mahkemeye gider de ondan. Orman yakmak, orman açmak, ağaç kesmek suçundan gider... Her yıl mutlak iki kere orman suçundan mahkemededir... O sana dediği lâflarl, hep mahkemelerde ezber etmiştir."

c. Orman suçlarına ilişkin yargılama sürecinin sorunlu yanları eserde gözler önüne serilmektedir. Bunun en iyi örneği İsmail Efendi olarak bahsedilen orman muhafaza memurunun aktardıklarıdır. ${ }^{52}$ İsmail Efendi daha önce görev yaptığı Karaören'de bir tarla açma olayı nedeniyle tuttuğu zabıtla başlayıp yıllarca devam eden yargılamayı, failin olaydan nasıl kurtulduğunu ve kendisi hakkındaki şikayetlerle nasıl sürgün edildiğini detaylıca anlatmaktadır. İsmail Efendi anlattıklarını şu sözlerle bitirmektedir: “... Şimdi baktı ki köylü, tarla açana ceza yok. Herkes tarla açacak. Üstelik ormancıyı da yerinden atıyorlar... Yerimden atıldı̆̆ıma bir yüreğim yanıyor ki... sorma Bey..."

d. Orman siyasi propagandanın önemli araçlarından biri haline gelmiştir. Çok partili yaşamın ilk yıllarında siyasetçiler ormanı oy kazanmak için kullanmaktadır. Köylünün ormandan beklentileri onun oy eğiliminde belirleyici role sahiptir. Oy köylü için elinde olan ve isteklerini yaptırabilmenin tek aracıdır. Yukarıda adı

\footnotetext{
${ }^{49}$ Bölüm 16- Bitmez, Tükenmez Davalar, s. 88.

${ }^{50}$ Bölüm 2- İnsan ve Orman, s. 19.

${ }^{51}$ Bölüm 7- Orman İçinde Yaşayanlar, s. 44.

52 Bölüm 6- Doğranan Ormanlar, s. 37-38.
} 
geçen Babacık yazara bazı düşüncelerini aktardıktan sonra şöyle der: 53 "Hükümet bunu böyle yapsın. Böyle yaparsa reyimiz hep kendisinin olsun. Reyimiz öyle hükümete kurban olsun. Ormanı da kurtulur.” Benzer şekilde, tapulu kesimler bölümünde aktarılan ve biri eski iki milletvekilinin bir tapulu kesim işi için orman işletme müdürünü ziyarete gelmesi ve yönlendirici, baskı altında bırakıcı konuşmalar yapması, o dönem siyasetin ormanlar ve ormancılıkla ilişkisini ortaya koymak açısından anlamlıdır.

e. Köylünün ekosistem, biyolojik çeşitlilik, ormanın işlevleri gibi konularda, bilimsel ve teknik terimlerle ifade edilmese de oldukça bilgili olduğu röportajlardan anlaşılmaktadır. Doğaldır ki bu bilgi geleneksel bilgi veya vatandaş bilimi bilgisidir. Yine Babacık olarak adlandırılan köylünün şu sözleri bu saptamanın en iyi kanıtlarından biridir: ${ }^{4}$ "Şu dağa, hani gündoğuda kel bir dağ var ya, ona Topalcevizin dăg derler. O zamanlar, yani benim delikanlılı̆̆ımda öyle kel değildi. On yıl önce bile. Yangın üstüne yangın, yangın üstüne yangın öyle kaldı işte dă̆. Eskiden her adımda bir pınar olurdu. Şimdi tüm kurudu. Şimdi her yer keskin, bıçak gibi kayalıktır. Eskiden azıcık olsun kaya göremezdin. Orman yanınca sular toprağı aldı götürdü. Kayalar kaldı meydanda. Sonra kardaş bir geyikler vardı Topalcevizin dağında; sürüyle. Ava giderdik. Bir günde on tane geyik vurduğumu biliyorum. Otuzu kırkı bir arada, Topalcevizin dă̆ında... Koca boynuzlu, kırmızı, ışıl ışıl geyikler. Şimdi bir tanesi bile kalmadı. Başlarını aldılar aldılar gittiler.",

f. Yanan Ormanlarda 50 Gün Yörükler ve Tahtacılık kültürü hakkında da önemli bilgiler içermektedir. Yörükler yaz aylarını yaylalarda geçirip kasım ayında sahile inerler. Ancak sahillerde her yer tarla olduğundan onlara ormanlardan başka yaşam alanı kalmamıştır. Musa Dede isimli bir yörük bu durumu şöyle anlatmaktadır: 55 “... Bizimki ölüm artık. Yürüklük öldü gitti. Dayanamadık bu işkencelere. O köyden sövüle dövüle o köye atılmă̆a dayanamadık. Hükümet bize tarla versin diye müracaat ettik. Olmadl. Kimse bakmadı halimize. Bize tarla. Başka çare kalmadı. Bizim için sı̆̆ınacak bir ormanlar kaldı. Ormanlarda da Bakım Memurlarıyla başımız dertte. Onlara bir parça dünyalık ayırmak gerek. Yoksa... Orman yüzü de göremeyiz...” Yazar eserde tahtacılara özel bir bölüm ayırmıştır. Bu bölümde onları şu şekilde tanıtır:56 “... Tahtacılar Toroslarda ăgaç kesmek, tahta biçmekle geçinen bir obadır. Bunlar Maraştan Marmarise kadar olan dağlarda barınırlar. Tahtacılıktan başka bir iş görmezler... Yazın dă̆larda kışın sahildedirler. Hiçbir hayvan beslemezler. Ne koyun, ne keçi, ne inek... Yalnız her evin bir, birkaç katırı vardır. Tahtacıların yürükler gibi develeri de yoktur. Ama onlar gibi tahtacıların evleri de çokluk kıl çadırdandır.,"

g. Eser 1954 yılında yapılan gözlem ve röportajlara dayanmaktadır. Öncesinde 1937 yılında çıkan Orman Yasası yürürlüktedir, ancak bu yasa 1945 yılında bir 1950 yılında da iki kez önemli değişikliklere tabi tutulmuştur. 1946 yılında çok partili rejime geçilmiş ve 1950 yılında Demokrat Parti iktidara gelmiştir. Yeni bir orman yasasından söz edilmektedir. Bu konuyla ilgili olarak Ali Çavuş olarak bahsedilen tahtacının yorumu dikkate değer niteliktedir:"57 "Türkiyede ne kadar orman kanunu çıkmışsa, her kanundan sonra bir orman tıraşlaması olmuştur. Ormanları orman kanunları bitirmiştir.” Yazar Ali Çavuş'un bu sözlerini aktardıktan sonra hemen ardından kendi yorumunu da katar: "Allah, kalan ormanlarımızı, -orman kalmış, şayet köşede bucakta bir iki dikili ă̆aç kalmışsa- bu yeni çıkacak kanundan esirgesin."

h. Eserde yer yer keçi-orman ilişkisi de yer almakta ve nihayet son bölümde yazar bu ilişkiye dair yorumunu katmaktadır: ${ }^{58}$ "Türkiyede 15 milyon keçi tesbit edilmiştir. Bu doğru değildir. Herkes bilir ki vergiden kaçmak için köylü keçisinin ancak dörtte birini yazdırır. Ben de çok iyi bilirim. Buna göre Türkiyede altmış milyon keçi vardır. Haydi biz yanılmış olalım da otuz milyon keçi var sayalım. Bu otuz milyon keçi nedir bilir misiniz? Türk ormanlarına girmiş otuz milyon balta... Mübală̆a ettiğimi sananlar gitsinler de ormanları bir görsünler. Böyle yangınlar, açmalar, keçiler olmasaydı o yüce dağlardaki ormanların biteceği mi vardı. Ama bitmiş. Ama orman denecek orman kalmamış."

\subsection{Tartışma}

1946 yılında çok partili hayata geçilmesi ve 1950 yılındaki seçimlerde iktidarın el değiştirmesiyle başlayan süreç, çevrenin de merkezin elinde tuttuğu siyasal iktidara ortak olmaya başlaması süreci olarak değerlendirilebilir

${ }^{53}$ Bölüm 6- Ormanı Bizden Değil, Bizi Ormandan Kurtarın!, s. 64.

${ }^{54}$ Bölüm 5- Ağaç Boğucuları ve Boğulan Ağaçlar, s. 32-33.

${ }^{55}$ Bölüm 12- Yaylaların Masalı, s. 70.

${ }^{56}$ Bölüm 14- Tahtacilar, s. 77.

${ }^{57}$ Bölüm 14- Tahtacılar, s. 80.

${ }^{58}$ Bölüm 18- Orman Dertlerinin Biricik Çaresi, s. 98. 
(Akıncı ve Usta, 2015). Türkiye'de 1933-1950 döneminde devlet öncülüğünde kalkınma modeli uygulanmış ve İkinci Dünya Savaşı'na rağmen çok önemli bir kalkınma hamlesi gerçekleşmiştir (Koçtürk ve Gölalan, 2010). 1950-1960 arası ise devletçi ekonomiden liberal ekonomi politikalarına geçişe sahne olmuştur (Kanca, 2012). Cumhuriyet'in ilk yıllarından itibaren kırsal kalkınma konusu devletin öncelikli gündem maddelerinden biri olmuş, bu amaçla 442 Sayılı Köy Kanunu'nun çıkarılmasından aşarın kaldırılmasına, çiftçiyi topraklandırma hareketlerinden köy enstitülerinin kurulmasına kadar pek çok çalışma yapılmıştır (Erdönmez, 1994). Buna rağmen yüzyıllara dayanan, birikmiş kırsal alan sorunlarının bütünüyle çözümü söz konusu olamamıştır. 1950 yılında Demokrat Parti iktidarıyla birlikte traktör dışalımına koşut olarak tarımda hızlı bir gelişme süreci yaşanmış, ancak toprak reformu yapılmamış ve altyapısı yetersiz olan ülkede tarım sektörü tıkanarak kente doğru göç süreci başlamıştır (Öztürk, 2008).

Yanan Ormanlarda 50 Gün bu koşullardaki Türkiye'nin kırsal toplumuna ve özellikle orman köylerine 1şık tutmaktadır. Her ne kadar eserin konusu orman yangınları olsa da, ormanların durumu ve ormanszılaşmadan kırsal toplulukların özelliklerine kadar geniş kapsamlı bir doğa ve toplum gözlemi niteliği taşımaktadır. Örneğin Yaşar Kemal'in müteahhit işletmeciliğine ilişkin saptamaları ile 1955 yılında Prof. Dr. Fikret Saatçioğlu'nun Antalya'da gerçekleştirdiği tatbikatlardan elde ettiği sonuç (Saatçioğlu, 1955) aynı yöndedir. Benzer şekilde, İnal (1967) tarafından ülke ormanlarının genel durumu ile ilgili yapılan saptama; ormanların yakma, tarla açma, hayvan otlatma, kaçakçılık vb. nedenlerle azalması ve bu durumun toprak ve su rejimi üzerindeki olumsuz etkileri ile Yaşar Kemal'in gözlemleri neredeyse birebir örtüşmektedir: Türkiye'de orman varlığı, eserin yazıldığı dönem öncesinde önemli miktarda azalmıştır. Gerçekten de yapılan bir araştırmaya göre yalnızca Antalya'da 1926-1946 arasını kapsayan 20 yıllık dönemde her yıl 3 bin 700 ha orman azalması meydana gelmiştir. Yalnızca Antalya'da görülen bu azalma oransal olarak bütün ülke ormanlarına yayıldığında, yurt çapında her yıl 100 bin hektarlık ormansızlaşmanın meydana geldiği anlaşılmaktadır (Diker ve Savaş, 1947).

Ormanların içinde ya da civarında yaşayan köylülerin ormanlara verdiği zararlar bir yandan onların yaşam koşulları ile ilgiliyken diğer yandan da 1937 yılında çıkarılan 3116 Sayılı Orman Kanunu'nun ormanlardan parasız yararlanma hakkına son vermesiyle ilişkilidir. Türkiye'de orman tahriplerinin ana nedenleriniden birisi 1857'den 1937'ye kadar çıkarılan ve sayıları yirmiye varan orman kanunlarından on beşinin ormanlardan bedava faydalanmayı mümkün kılması ve bedavacılık zihniyetini kökleştirmesidir (Diker, 1947). Parasız yararlanma (cibali mübaha) geleneğinin ortadan kalkması sonucunda orman idaresi ile bu geleneği sürdürmek isteyen veya sürdürmek zorunda olan köylüler arasında bitmek tükenmek bilmeyen çatışmalar ortaya çıkmıştır (Gümüş, 2018). Yoksul orman köylüsü yanıbaşındaki kaynağa yabancılaştırılmış ve geçerli üretim ilişkilerinden soyutlanmıştır (Çağlar, 1979). Yüzyıllarca geçerli olan kontrolsüz yararlanma alışkanlı̆̆ı elinden alınan orman köylüsü, zorlu yaşam koşullarının da etkisiyle ormandan yasaya aykırı şekilde yararlanmaya devam etmiş, bu ise orman suçları sayısında hızlı bir artışa neden olmuştur. Gerçekten de 1937 yılında ülke çapında işlenen ve kayıtlara geçen orman suçu sayısı 5 bin 351 iken, her yıl artarak 1960 yılında 108 bin 744'e (Özdönmez, 1965); her 100 bin nüfus başına işlenen orman suçu sayısı ise 1951'de 238 iken 1960'ta 392'ye yükselmiştir (Özdönmez, 1973).

Orman-halk ilişkilerinde yaşanan sorunlar, orman suçlarının artması ve çok partili rejime geçiş nedeniyle ormanlar üzerinden yapılan siyasi propaganda, orman köylüsünün sıkıntılarının azaltılması için 1950'lere doğru bazı girişimlerin gerçekleşmesine yol açmış (Bingöl, 1990), ancak bu girişimler yeterince etkili olmamıştır. 1950 yılında peş peşe çıkarılan iki yasa ile orman-halk ilişkilerinde meydana gelen gerilim azaltılmak istenmiştir. Bunlardan 5658 Sayılı Yasa 1945 yılında 4785 Sayılı Yasa ile devletleştirilen köy ve belediye ormanları ile özel ormanların sahiplerine iadesini mümkün kılmıştır. 5653 Sayılı Yasa ise muhafaza niteliği taşımayan ve devamlı orman hasılatı vermeyen makilikleri orman tanımı dışarısına çıkararak yoksulluk içerisindeki köylü için yeni tarım alanları yaratma amacı gütmüştür. Gümüş (2018)'e göre bu yasal düzenlemelerle orman konusu siyasal bir malzeme haline gelmiştir. Bütün bunların altında yatan neden ise Yaşar Kemal'in Yanan Ormanlarda 50 Gün'de kapsamlıca açıkladığı gerçeklerdir. Bu gerçekler orman köylüsünün yoksulluğu ve çaresizliği nedeniyle ormanlardan yasal olmayan yollarla yararlanma zorunluluğu, yeniden yapılandırılan devlet ormancılık örgütünün ormanları korumak konusundaki istek ve azmi, birbiriyle çelişen bu iki durumun çözümü için alınması gerekli sosyal ve ekonomik tabanlı önlemleri almak yerine ormanlardan siyasi çıkar sağlamanın peşinde olan siyaset ile köylünün çaresizliği ile yasaların boşluklarını kişisel çıkarları için kullanan ticaretten oluşmaktadır. Yaşar Kemal, bir gazeteci ve sanatçı olmanın ötesinde bir yöntemle çalışarak, hassas ve kapsamlı gözlemlerle bu gerçekleri saptamış ve kendine has yazı üslubunun verdiği lezzetle tarihe not düşmüştür.

\section{Sonuç ve Öneriler}

Yanan Ormanlarda 50 Gün aynı zamanda bir orman ve ormncılık tarihi okuması niteliğindedir. Eserin kaleme alınmasının üzerinden neredeyse 70 yıl geçmiş olmasına rağmen günümüz ormancılığına 1şık tutacak çok değerli 
bilgileri bünyesinde barındırmaktadır. Orman yangınları, ormandan tarla açma, kaçak kesimler, keçi sorunu, orman köylüsü, orman halk ilişkileri, ormancılık üzerinde siyasetin etkisi gibi pek çok konuda eser aydınlatıcı bir tarihi belge durumundadır. Özellikle orman işletmeciliğinde 1870 Orman Nizamnamesi hükümleri gereği müteahhit işletmeciliğinden 1937 tarihli Orman Kanunu hükümleri gereği devlet orman işletmeciliğine dönüşümünün yararlarını Yanan Ormanlarda 50 Gün net bir şekilde ortaya koymaktadır.

Doğa ve orman hemen bütün sanat dallarının ve edebiyatın vazgeçilmez ilgi alanlarından biridir. Ne var ki sanat ve edebiyat doğayı ve ormanı bir estetik unsur olarak işlemekten daha derin bir kapsama geçiş yaptığında toplum için çok daha yararlı bir işleve bürünmektedir. Bu işlev doğa toplum ilişkilerinde bilimin yetersiz kaldığı bir boyutu gözler önüne sermektir. Bunun için doğaya ve ormana, içinde barındırdığı tüm diğer unsurlar ile yine içinde yaşayan insan topluluklarına ve elbette bütün bunların aralarındaki ilişkilere bilimin soğuk nesnelliğinden çok sanatın sıcak hassasiyetiyle de yaklaşma gerekliliğini akıldan çıkarmamak gerekmektedir.

Diğer yandan ormancılık tarihi çalışmaları ile ormancılık politikasının tarihsel temellerinin araştırılmasında yazılı belgeler oldukça büyük öneme sahiptir. Bununla birlikte her dönem ve her konuyla ilişkili yazılı bilimsel eser veya tarihi belge bulmak mümkün olmayabilir. Bu tür durumlarda edebi eserler de dikkate alınması gereken yazılı eserler arasında değerlendirilmelidir. Doğaldır ki edebi eserler bilimsel eserler kadar nesnel olmayacaktır. Hatta kimi zaman edebiyatın özelliği gereği, edebi eserlerde gerçekler olduğundan farklı olarak da dile getirilebilir. Buna rağmen edebi eserlerin, bu eserlerden elde edilecek bilgilerin başlı başına veri olarak kabul edilmemesi koşuluyla, bilimsel boşlukları doldurmakta önemli rol oynayacak potansiyele sahip olduğu unutulmamalıdır. Yanan Ormanlarda 50 Gün gibi kapsamlı gözlemlere dayanan ve bilim adamı titizliğiyle kaleme alınmış edebi eserler bu açıdan çok daha yararlı sonuçlar verecektir.

Ormancılık toplumla yoğun ilişkiler içeren bir uğraşı ve bilimsel disiplindir. Ormancılık araştırmalarında, özellikle ormancılığın sosyal boyutunu içeren çalışmalarda edebi eserlerin birer veri kaynağı olarak kullanılabileceğini bu çalışma ortaya koymaktadır. $\mathrm{Bu}$ nedenle, gerek ormancılık araştırmalarının gerekse ormancılık eğitiminin edebiyat ile daha yakın ilişski içerisinde bulunması yalnızca bir gereklilik değil bazı durumlarda bir zorunluluk olarak görülmelidir.

\section{Teşekkür}

Makaleyi okuyarak görüş ve önerileriyle katkı yapan Seçil Yurdakul Erol, Hasan Tezcan Yıldırım ve Gizem Şahin'e teşekkür ederim.

\section{Kaynaklar}

1. Akıncı, A., Usta, S. (2015). Türkiye'de çok partili hayata geçişte etkili olan iç faktörlerin analizi. KMÜ Sosyal ve Ekonomik Araştırmalar Dergisi 17 (29), 41-52.

2. Aktaş, Ş. (2009). Edebi metin ve özellikleri. Atatürk Üniversitesi Türkiyat Araştırmaları Enstitüsü Dergisi (39), 187-200.

3. Andı, M.F. (2006). Türk edebiyatında roman: Cumhuriyet devri. Türkiye Araştırmaları Literatür Dergisi 4 (8), 165-201.

4. Armağan, Y. (2015). Kiyamete kadar Yaşar Kemal'i okumak. Hacettepe Üniversitesi İletişim Fakültesi Kültürel Çalışmalar Dergisi 2 (1), 347-362.

5. Ayaydın, G.Ö. (2003). Yaşar Kemal'in İstanbul'una Çevreci Bir Yolculuk. Yüksek Lisans Tezi (yayımlanmamış). Bilkent Üniversitesi Türk Edebiyatı, Ankara, 143 s.

6. Ayaz, H. (2014). Çevreci eleştiri üzerine genel bir değerlendirme. Uluslararası Türkçe Edebiyat Kültür Ĕ̈itim Dergisi 3 (1), 278-292.

7. Aydemir, M., Yılmaz, N. (2018). Bir gerçek iki hayal: Yaşar Kemal ile Kemal Tahir'in romanlarına yansıyan Doğu insanı. Sosyal Bilimler Dergisi 5 (22), 214-231.

8. Bingöl, İ. (1990). Geçmişten Günümüze Ormanlarımız ve Ormancılı̆̆ımız. Ormancılık Eğitim ve Kültür Vakfi Yayın No. 4: İstanbul, 157 pages.

9. Buell, L., Heise, U.K., Thornber, K. (2011). Literature and environment. The Annual Review of Environment and Resources (36), 417-440.

10. Çağlar, Y. (1979). Türkiye'de Ormancılık Politikası (Dün). İz Yayıncılık: Ankara, 463 pages.

11. Çankaya, E. (2013). Köy edebiyatı ve Türk edebiyatında köye "içerden” bakış doğuşu, etkileri, sonuçları. Turkish Studies 8 (4), 473-488. 
12. Diker, M. (1947). Türkiye'de Ormancılık: Dün-Bugün-Yarın. TC Tarım Bakanlığı Orman Genel Müdürlüğü Yayınlarından Sayı 61: Ankara, 132 pages.

13. Diker, M., Savaş, K. (1947). Yurdda Orman Azalması. TC Tarım Bakanlığı Orman Genel Müdürlüğü Yayınlarından Sayı 73: Ankara, 31 pages.

14. Erdönmez, C. (1994). Türkiye’de Kırsal Kalkınma. Türkiye 1. Tarım Ekonomisi Kongresi, 88-97. 8-9 Eylül 1994, İzmir.

15. Gümüş, C. (2018). Türk Orman Devrimi. Türkiye Ormancılar Derneği Yayın No. 43: Ankara, 306 pages.

16. Irmak, E. (2018). Eski Köye Yeni Roman. İletişim Yayıncılık: İstanbul, 323 pages.

17. İnal, S. (1967). Orman ve ormancılık problemlerimize toplu bir bakış. Ístanbul Üniversitesi Orman Fakültesi Dergisi B17 (2), 31-44.

18. Kanca, O.C. (2012). 1950-1960 arası Türkiye'de uygulanan sosyo-ekonomik politikalar. Mustafa Kemal Üniversitesi Sosyal Bilimler Enstitüsü Dergisi 9 (19), 47-63.

19. Kayayerli, F.D. (2012). Türkiye'de Röportaj Geleneği Bağlamında Yaşar Kemal'in Röportajları Üzerinden Nitel Bir Değerlendirme. Yüksek Lisans Tezi (yayımlanmamış). İstanbul Bilgi Üniversitesi Sosyal Bilimler Enstitüsü Medya ve İletişim Sistemleri Programı, İstanbul. $132 \mathrm{~s}$.

20. Kemal, Y. (1955). Yanan Ormanlarda 50 Gün. Türkiye Ormanc1lar Cemiyeti: Ankara, 100 pages.

21. Kemal, Y. (2017). Yanan Ormanlarda Elli Gün. Yap1 Kredi Yayınları: İstanbul, 230 pages.

22. Koçtürk, O.M., Gölalan, M. (2010). 1923-1950 Türkiye ekonomisinin yapısal analizi. Üçüncü Sektör Kooperatifçilik 45 (2), 48-65.

23. Moran, B. (2002). Edebiyat Kuramları ve Eleştiri. İletişim Yayınları: İstanbul, 352 pages.

24. Oktar, S., Varlı, A. (2010). Türkiye’de 1950-1954 döneminde Demokrat Parti’nin tarım politikası. Marmara Üniversitesi İBF Dergisi 28 (1), 1-22.

25. Opperman, S. (1999). Ecocritism: Natural World in the literary viewfinder. Hacettepe University Journal of Faculty of Letters 16 (2), 29-46.

26. Önertoy, O. (1983). Yaşar Kemal ve Çukurova. Türk Dili (Şubat), 147-166.

27. Özbek, B.H. (2017). Namık Kemal'in romanlarında romantik doğa algısı. Yeni Türk Edebiyatı Araştırmaları 9 (17), 151-163.

28. Özdăg, U. (2017). Çevreci Eleştiriye Giriş. Ürün Yayınları: Ankara, 174 pages.

29. Özdönmez, M. (1965). Türkiye’de Orman Suçları nevileri, Sebepleri ve Önlenmesi Çareleri Üzerine Araştırmalar. Tarım Bakanlığı Orman Genel Müdürlüğü Yayını, Yayın No. 422: İstanbul, 156 pages.

30. Özdönmez, M. (1973). Orman suçları ile ilgili af kanunları ve sonuçları. İstanbul Üniversitesi Orman Fakültesi Dergisi B23 (2), 48-61.

31. Öztürk, Ş. (2008). Kırsal yoksulluk ve neoliberal ekonomi politikaları. Uluslararası Sosyal Araştırmalar Dergisi 1 (5), 605-634.

32. Sümer, Z.S. (2016). Bozkırdan Hikayeler: Filiz Kılıçel’in Öykülerinde Çevreci Eleştiri Bağlamında Doğa Edebiyatını Yeniden Keşfetmek. Uluslararası Sempozyum: Geçmişten Günümüze Bozkır, 741-750, Konya.

33. Saatçioğlu, F. (1955). Antalya mıntıkası ormanlarında yapılan tatbikatların ana neticeleri. Ístanbul Üniversitesi Orman Fakültesi Dergisi B5 (2), 143-155.

34. Şeker, A. (2019a). Yaşar Kemal'in romanlarında ekososyoloji. Ankara Üniversitesi Dil ve Tarih-Coğrafya Fakültesi Türkoloji Dergisi 23 (1), 158-176.

35. Şeker, A. (2019b). Yaşar Kemal'in romanlarının sosyolojisinde insan sevgisi ve değerinin varoluşsal kaynaklar1. Folklor Edebiyat 25 (98), 371-385.

36. Westling, L. (2006). Literature, the environment, and the question of the posthuman. In Nature in Literary and Cultural Studies: Transatlantic Conservation on Ecocritism Ed. Catrin G., Sylvia M., pp. 25-48.

${ }^{i}$ Bölüm 11- Ormanı Bizden Değil Bizi Ormandan Kurtarın, s.61. 